\title{
TRANSIENT PERFORMANCE OF TWO-ELECTRON REGIME BIOREACTORS THAT CONTAINED UNACCLIMATED BIOCATALYSTS AFTER FEEDING PERCHLOROETHYLENE
}

\author{
Cuauhtémoc Ulises MORENO-MEDINA ${ }^{1}$, Héctor Mario POGGI-VARALDO ${ }^{1 *}$, \\ Luz BRETON-DEVAL ${ }^{1}$ and Noemi RINDERKNECHT-SEIJAS ${ }^{2}$
}

\footnotetext{
${ }^{1}$ Departamento de Biotecnología y Bioingeniería, Centro de Investigación y de Estudios Avanzados del Instituto Politécnico Nacional. Avenida Instituto Politécnico Nacional 2508, Colonia San Pedro Zacatenco, Delegación Gustavo A. Madero, Ciudad de México, México, C. P. 07360

${ }^{2}$ Escuela Superior de Ingeniería Química y Extractivas, Instituto Politécnico Nacional. Edificio número 7 , Unidad Profesional Adolfo López Mateos. Colonia Lindavista, Delegación Gustavo A. Madero, Ciudad de México, México, C.P. 07738

*Corresponding author: r4cepe@yahoo.com
}

(Received November 2015; accepted February 2016)

Key words: fluidized bed, partially-aerated methanogenic, simultaneous methanogenic-denitrifying, zero-valent iron

\begin{abstract}
The objective of this work was to assess the impact of perchloroethylene (PCE) and coupled zero valent iron (ZVI) filters on the transient performance of fluidized bed bioreactors (FBBRs) operated in simultaneous electron acceptors modes. Four lab scale, FBBRs were implemented. Two FBBRs were operated as simultaneous methanogenicdenitrifying (MD) units, whereas the other two were operated in partially-aerated methanogenic (PAM) mode. In the first period all FBBRs received a synthetic wastewater with $1 \mathrm{~g}$ COD-methanol/L. In a second period, all the FBBRs received the synthetic wastewater plus $80 \mathrm{mg} \mathrm{PCE} / \mathrm{L}$. At the start of period 2, one MD and one PAM FBBRs were coupled to side sand-ZVI filters. All bioreactors anchored microbial consortia unacclimated to PCE. In this work, bioreactor performance in the full period 1 and the first 15 days of period 2 (transient state) is reported and discussed. The chemical oxygen demand and the nitrate removal efficiency of the FBBRs did not decrease between period 1 and period 2, i.e., upon PCE addition, particularly for MD bioreactors. On the contrary, specific oxygen uptake rate of all FBBRs in period 2 decreased by ca. 80 to $96 \%$ or more compared to period 1 . In period 2, PCE removals and dehalogenation efficiency were in the range of 81 to $94 \%$ and 73 to $90 \%$, respectively. The highest values corresponded to PAM bioreactors, particularly for that equipped with ZVI filter. Slight positive effects of ZVI filter on PCE removal and the dehalogenation efficiencies were observed in the PAM ZVI bioreactor configuration. It is concluded that the simultaneous electron acceptor type (PAM vs. MD) had a significant effect on the bioreactor performance, whereas the coupling to ZVI filters only had a slight positive effect on the bioreactor performance in the PAM-ZVI bioreactor.
\end{abstract}

Palabras clave: lecho fluidizado, metanogénico con aereación parcial simultáneo, metanogénico-desnitrificante simultáneo, hierro metálico 


\section{RESUMEN}

El objetivo del presente trabajo fue evaluar el impacto del filtro acoplado de hierro cero-valente sobre el desempeño de biorreactores de lecho fluidizado (BLEF) operados con aceptores simultáneos de electrones y sometidos a altas concentraciones de percloroetileno (PCE). Se utilizaron cuatro BLEF a escala laboratorio, dos operados en metanogénesis con aireación parcial (MAP) y dos metanogénicos-desnitrificantes (MD). En el primer periodo todos los BLEF se alimentaron con agua residual sintética y $1 \mathrm{~g}$ de COD-metanol/L. En el segundo periodo todos los BLEF recibieron la misma agua residual sintética más $80 \mathrm{mg}$ PCE/L. A un BLEF MAP y un BLEF MD se les acopló un filtro de arena-partículas de hierro metálico. A partir de ese momento se operó lo que denominamos estado transitorio de los primeros 15 días. Todos los biorreactores fueron inoculados originalmente con un consorcio no aclimatado a PCE. En este trabajo se reporta el periodo 1 completo y el efecto inicial (15 días) del PCE y los filtros de arena-hierro metálico acoplados a los biorreactores (periodo 2). La eliminación de la demanda química de oxígeno y del nitrato se mantuvo en valores similares entre el periodo 1 y 2, particularmente para los BLEF MD. En contraste, la tasa de consumo de oxígeno específica en los BLEF se redujo entre un $80 \%$ a un $96 \%$ en el periodo 2 , en comparación con el periodo 1 . La eliminación de PCE y la eficiencia de deshalogenación en el periodo 2 estuvieron en el intervalo del 81 al $94 \%$ y del 73 al $90 \%$, respectivamente. En general, los bioreactores MAP presentaron mayores valores de esas variables que los biorreactores MD. Los valores más altos de eliminación de PCE y eficiencia de deshalogenación se observaron en el MAP con filtro acoplado, aunque la superioridad de éste sobre MAP sencillo fue ligera.

\section{INTRODUCTION}

Perchloroethylene (PCE) is an ubiquitous chlorinated organic compound very commonly found in contaminated groundwater (Kao et al. 2003). This PCE is a chlorinated aliphatic compound, considered hazardous, thus it is included in the priority list of hazardous pollutants of USA, Mexico, and other countries (OEHHA 2001, NTP 2016). The PCE in drinking water has a significant risk for human health, such as cancer of colon, rectum, lung, breast, kidney, bladder and leukemia (Paulu et al. 1999, Aschengrau et al. 2003). Other negative effects are damage to eyes, ears, and nervous system development (Lagakos et al. 1986).

Biodegradation of PCE is generally carried out in anaerobic environments, although very often accumulation of significant traces of intermediate less chlorinated ethylenes, such as trichloroethylene (TCE), trans 1-2 dichloroethylene (trans 1-2 DCE), cis 1-2 dichloroethylene (cis 1-2 DCE) and vynil chloride (VC) has been reported (Bagley and Gossett 1990, El-Fantroussi et al. 1998, Ohandja and Stuckey 2007).

The use of simultaneous or sequenced electron acceptor electron for the wastewater treatment were recently tested with success, but their potential and other approaches need to be investigated for its potential use in the pump and treat system (P\&T)
(Zárate-Segura et al. 2005, Reyna-Velarde et al. 2005, Garibay-Orijel et al. 2005, Chen et al. 2013, Frascari et al. 2013, Mitra and Gupta 2013).

The P\&T is an option for groundwater (bio)remediation. This type of on-site (or ad situ) approach came into wide use in the early to mid- 80s (EPA 1996) in spite of being more expensive than in situ remediation. Interestingly, about $72 \%$ of the initially P\&T facilities installed from 1982 to 2005 in the USA are still in operation (Majone et al. 2015). P\&T is still a recommended option in cases such as highly porous soils that allow fast flow rates, fractured rock in the subsurface soil where the plume may spread easily, and proximity to a receptor site or individuals, for instance when groundwater is used as drinking water supply (Alther 2004).

Zero-valent iron (ZVI) was effectively applied for the remediation of PCE and other chlorinated organic aliphatic compounds, particularly on underground permeable reactive barriers (PRB) for groundwater remediation (Zolla et al. 2007, Poggi-Varaldo et al. 2009). ZVI can create ecological niches that possibly would improve the microbial activities favorable to chlorinated organic compounds removal (Bruton et al. 2015).

This interaction of biological and ZVI treatments in bioreactors is of great interest, although the information in the open literature is still scarce, and focused mainly on batch processes. Wang and Tseng (2009) 
observed $100 \%$ TCE removal efficiencies (initial concentration $24.6 \mathrm{mg} \mathrm{TCE} / \mathrm{L}$ ) in both batch units, one with $\mathrm{ZVI}+\mathrm{H}_{2}$ and the other with $\mathrm{ZVI}+\mathrm{H}_{2}+$ acclimated inoculum at 18 and 15 days of incubation, respectively. Batch biotic units contained 100 $\mathrm{mL}$ of PCE acclimated inoculum (sludge) and 20 $\mathrm{g}$ of ZVI filings. The authors found ethene at 0.36 $\mathrm{mg} / \mathrm{L}$ and ethane at $0.12 \mathrm{mg} / \mathrm{L}$. However, they did not report dehalogenation efficiency. Removals of p-chloronitrobenzene in bioreactors seeded with anaerobic sludge in combination with ZVI were higher than those of control bioreactors with only anaerobic sludge (increase of $47 \%$, compared to sludge control; Zhu et al. 2013). The experiments were performed in batch small reactors (serum bottles, $100 \mathrm{~mL}$ ), inoculated with anaerobic sludge (1.5 g of volatile suspended solids (VSS)/L, previously acclimated to the pollutant) from a municipal wastewater plant and loaded with 5 $\mathrm{g} / \mathrm{L}$ ZVI $22 \mathrm{~mm}$ average diameter. Recently, Zhou et al. (2014) observed a $92 \%$ concentration decrease of 1,1,1-trichloroethane (TCA) in synthetic groundwater in serum bottles $(100 \mathrm{~mL})$ inoculated with bio-beads. The bio-beads consisted of anaerobic bacteria-ZVI granules and activated carbon particles, with polyvinyl alcohol as the immobilization matrix. Before the experiment, the bio-beads were submitted to six batch cycles with anaerobic medium and $160 \mathrm{mg}$ TCA/L. That is, the consortium was acclimated to the toxicant.

Other authors reported the use of hybrid systems (ZVI-coupled to bioreactors with two electron acceptors). Herrera-López et al. (2008) observed a PCE removal higher than $99.8 \%$ in both partially-aerated methanogenic (PAM) and methanogenic-denitrifying (MD) batch reactors, respectively, equipped with ZVI-sand bags and seeded with bio-particles sampled from fluidized bed bioreactors acclimated to PCE. It was not found significant differences in PCE removals in the units fitted with ZVI and the biological units. The authors concluded that former acclimation to PCE of bioreactors might have lead to already high biotic PCE depletions and any improvement ascribed to ZVI was not detectable. As mentioned above, all FBBRs which were the source of inoculum were acclimated previously to up to $80 \mathrm{mg}$ PCE/L for 345 days, and fed with a wastewater with $1 \mathrm{~g}$ chemical oxygen demand (COD)-methanol/L, $80 \mathrm{mg} \mathrm{PCE} / \mathrm{L}$, and minerals. Yet, the effect of ZVI side treatment on PCE depletion of FBBRs operated with PCEunacclimated biomass was not tested.

We hypothesized that ZVI would improve PCE removals in simultaneous electron acceptors mode FBBRs not previously acclimated to PCE. Therefore, the objective of this work was to evaluate the impact of a sudden feeding of PCE and coupled zero valent iron (ZVI) filters on the transient performance of fluidized bed bioreactors (FBBRs) operated in simultaneous electron acceptor modes where the bed bio-particles anchored microbial consortia unacclimated to PCE.

\section{MATERIALS AND METHODS}

\section{Experimental design and bioreactors}

Four lab scale, FBBRs were made of glass columns (5.4 cm diameter and $2 \mathrm{~mm}$ thickness) with a total capacity of $3.5 \mathrm{~L}$ and working volume of $2.8 \mathrm{~L}$. Peristaltic pumps were used for feeding (Masterflex C/L Cole Parmer pump, Barrington, Il, USA mod. 77120-50 low flux) and for effluent recirculation (Masterflex L/S mod. 7553-86, 6 to 600 rpm; Fig. 1). Bioreactors were operated at $35 \pm 2{ }^{\circ} \mathrm{C}$.

Quiescent volume of bio-particles bed in the bioreactors was $1 \mathrm{~L}$. Bio-particles consisted of granular vegetal-origin activated carbon (GAC), average $2 \mathrm{~mm}$ (Zárate-Segura et al. 2004). GAC was characterized by a porosity of $0.77 \%$, a Brunauer-Emmett-Teller (BET) -superficial area of $778 \mathrm{~m}^{2} / \mathrm{g}$, average pore size of $0.357 \mathrm{~m}^{3} / \mathrm{g}$, and average diameter of $1 \mathrm{~cm}$. An autochem II 2920 (micrometrics) instrument was used to measure the nitrogen adsorption isotherms at $-196{ }^{\circ} \mathrm{C}$ for determining the total pore volume and the specific surface area through the BET equation (Rouquerol et al. 1999).

The vegetal GAC was colonized by a methanogenic consortium. Initially, bioreactors were filled with $1 \mathrm{~L}$ of GAC (700 $\mathrm{g}$ of dried GAC). Methanogenic consortia produced in suspended growth bioreactors and unacclimated to PCE or other pollutants was used as inoculum (1 L). FBBRs were filled with a synthetic wastewater consisting of methanol $(1 \mathrm{~g} \mathrm{COD}-m e t h a n o 1 / \mathrm{L})$ and $0.17 \mathrm{~g} / \mathrm{L}$ of $\left(\mathrm{NH}_{4}\right)_{3} \mathrm{PO}_{4}$ as source of nutrients and alkalinity, respectively, dissolved in tap water. The FBBRs were batchoperated for three days with effluent recirculation to promote cell immobilization on support particles and to fluidize the support particles. At the $4^{\text {th }}$ day, the FBBRs were fed with an increasing amount of synthetic wastewater reaching a flow $(\mathrm{Q})=1 \mathrm{~L} / \mathrm{d}$ at day 15 , continuous effluent recirculation was kept at a recirculation flow $(\mathrm{Qr})=8.7 \mathrm{~L} / \mathrm{d}$ with a $30 \%$ bed expansion. The feeding of MD bioreactors was supplemented with $800 \mathrm{mg} \mathrm{KNO}_{3} / \mathrm{L}$.

ZVI filters consisted of $80 \mathrm{~mL}$ serum bottles filled with $28 \mathrm{~g}$ of ZVI filings and $28 \mathrm{~g}$ of sand. ZVI was obtained by filing an iron bar (L type) gathered from a local construction supplier. Before filing, the iron bar 

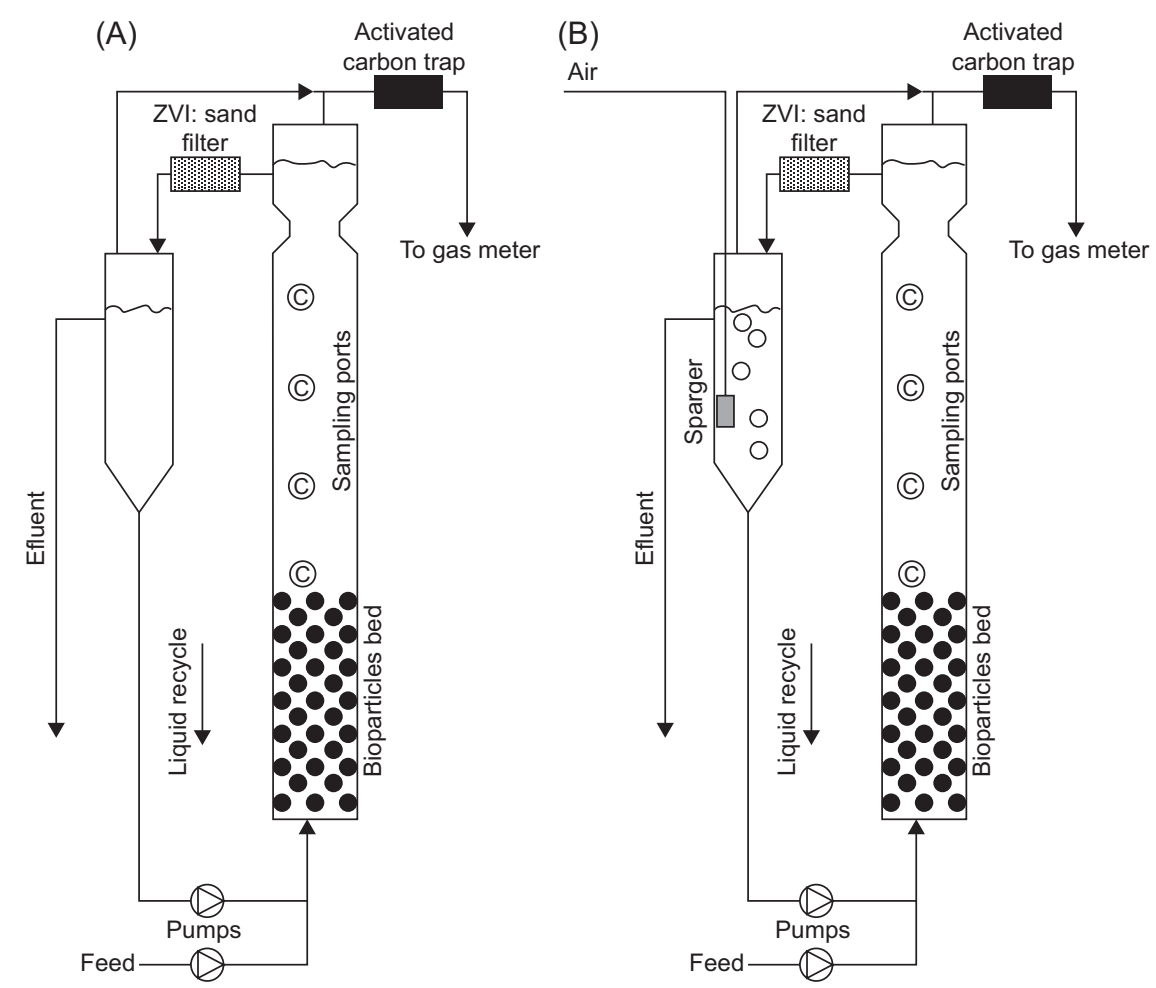

Fig 1. Diagram of the bioreactor set-up: (A) methanogenic-denitrifying (MD) regime, (B) partially aerated methanogenic regime (PAM). In period 2, one MD and one PAM were coupled to zero valent iron filters

was de-rusted and cleaned by a disk sander machine in Centro de Investigación y de Estudios Avanzados del Instituto Politécnico Nacional (CINVESTAV, in spanish) machine shop. After de-rusting and cleaning, the bar was filed and filings collected by a magnet and stored in gas tight flasks under inert nitrogen gas. Sand was from the same construction supplier, it was screened and the fraction that passed mesh 18 and was retained in mesh 35 , was selected. This fraction was washed twice in hot distilled water, dried, and stored before using.

The ZVI-sand filters were connected to the recirculation line, near the top of the fluidized bed bioreactor (Fig. 1). In PAM FBBRs, effluent exiting the ZVI-sand filters entered an aeration chamber fitted to the recirculation line where the effluent was continuously aerated before being re-circulated to the base of the bioreactors (Fig. 1B). Dissolved oxygen (DO) in aeration chamber was 2.5 to $4.0 \mathrm{mg} / \mathrm{L}$, whereas dissolved oxygen in bioreactor liquor on the top of the bio-particles bed was around 0.5 to $1.0 \mathrm{mg} / \mathrm{L}$.

Bioreactors were operated at $1 \mathrm{~d}$ hydraulic retention time, based on fluidized bed volume. In period 1 (168 d operation), two FBBRs were executed in PAM, whereas the other two in MD mode. The $\lambda$ parameter was set at $\lambda=9 \mathrm{~g} \mathrm{COD}-$ methanol $/ \mathrm{g} \mathrm{N}^{-\mathrm{NO}_{3}}{ }^{-}$and $\lambda=$ $1.75 \mathrm{~g}$ COD-methanol $/ \mathrm{g} \mathrm{O}_{2}$ for the MD and PAM, respectively (Garibay-Orijel et al. 2006). In the second period (15 days) all the FBBRs received the synthetic wastewater described above with methanol as carbon source ( $1 \mathrm{~g} \mathrm{COD-methanol/L)} \mathrm{and} \mathrm{supple-}$ mented with $80 \mathrm{mg}$ PCE/L. Also, one MD-FBBR and one PAM-FBBR were coupled to the ZVI-sand side filters. Hydraulic retention time in ZVI-sand filters was $21.5,0.75$ and $0.72 \mathrm{~min}$, based on flow-rate feeding, flow-rate recirculation, and total flow-rate, respectively. All bioreactors anchored microbial consortia unacclimated to PCE.

Data were processed following three experimental designs. In period 1 when PCE was absent from the feed-water and no ZVI filter was coupled, there was only one factor to compare at two levels: the regime of simultaneous electron acceptor.

Between period 1 and 2, the bioreactors in period 1 (two SEA, no PCE and no ZVI filter) were compared to selected bioreactors in period 2 (two SEA, PCE in the feed-water, no ZVI filter). That is, a factorial experiment with two factors at two levels (SEA, either PAM or MD; PCE in the feed-water, either 0 or $80 \mathrm{mg} / \mathrm{L}$ ) 
In period 2 when PCE was supplemented to the feed-water, the experimental design was another factorial $2^{2}$. Factors were the regime of simultaneous electron acceptor (SEA, either partially-aerated methanogenic, PAM, or methanogenic-denitrifying, MD), and coupling to ZVI side filters. All bioreactors contained biocatalysts that were not acclimated to PCE at the time that PCE feeding was started.

\section{Analyses}

The $\mathrm{pH}$ in the liquid streams was determined with a Beckman $\mathrm{f} 41 \mathrm{pH}$ meter. COD and other parameters were determined in the liquid streams. The COD and total Kjeldahl nitrogen (TKN) in the bio-particles were determined according the methods 5220 and $4500-\mathrm{N}_{\text {org }} \mathrm{C}$, respectively of the standard methods (APHA, 1998). TKN was determined in the bio-particles and virgin GAC. Biomass content in the bio-particles was estimated by conversion of TKN to VSS, the latter was calculated on the basis of the empirical formula $\mathrm{C}_{5} \mathrm{H}_{7} \mathrm{O}_{2} \mathrm{~N}$ for the biomass with a factor of $0.124 \mathrm{mg} \mathrm{N}-\mathrm{TKN} / \mathrm{mg}$ VSS biomass (Wentzel et al. 2003). Total suspended solids (TSS) in the bioreactor liquor above the fluidized bed was very low (in the range $50-120 \mathrm{mg} / \mathrm{L}$ ) and the TKN associated to those suspended solids was negligible.

Specific methanogenic activity (SMA) was determined according to Sorensen and Ahring (1993). Specific denitrifying activity (SDA) was evaluated by measuring the dissolved $\mathrm{NO}_{3}{ }^{-}$in serum bottles with bio-particles sampled from FBBRs following the method published in Sánchez et al. (2000). The specific oxygen uptake rate (SOUR) was determined according to Kristensen and Jorgensen (1992), using methanol as carbon source $(1 \mathrm{~g} \mathrm{COD} / \mathrm{L})$. The method relied on determining the DO consumption in biological oxygen demand in bottles filled with oxygen-saturated water and bio-particles. The DO was measured using an oxygen meter (YSI INC, model 57, USA) that fitted by design the neck of the bottle without entering airoxygen into the testing system.

PCE and its intermediate metabolites (TCE, cis, trans and 1-1 DCE, VC and ethylene) in liquid streams and solid matrices were determined by headspace in gas chromatography using a Perkin-Elmer chromatograph equipped with a flame ionization detector, a Perkin Elmer Elite-624 series capillary columns. In the head space technique the chlorinated compounds were volatilized and preserved in the space between the sample and the teflon-faced silicone septa. Samples were weighed and transferred into serum vials and hermetically closed with teflon-faced silicone septa and cramp aluminum seals. Afterwards, the serum vials were submerged in a solution of water/ ethylene glycol $(50 \%, \mathrm{v} / \mathrm{v})$ at $70 \pm 1{ }^{\circ} \mathrm{C}$ for $15 \mathrm{~min}$. After that, $1 \mathrm{~mL}$ of gas was sampled from the vial headspace and injected into the gas chromatograph. Based on the work of Peng and Wan (1997), it can be shown that the ratios of Henry's constants for TCE at 70 and $20^{\circ} \mathrm{C}$ in water is 6.03 , whereas the corresponding ratio value for PCE is 6.60. This shows the drastic increase of the partition coefficient between gas-liquid phases for the two of the most important metabolites in our work. Furthermore, with increased partition coefficients, the headspace technique likely efficiently expels the PCE and TCE from the liquid to the vapor phase of the vials. This argument is more valid for dichloroethylene (DCE), VC, and ethylene (ETH), since they are more volatile than PCE and TCE. Injector and detector temperatures were $200^{\circ} \mathrm{C}$ and $250{ }^{\circ} \mathrm{C}$, respectively. The temperature program of the column was as follows: start at $40^{\circ} \mathrm{C}$, followed by an increase of $6{ }^{\circ} \mathrm{C} / \mathrm{min}$ up to $119^{\circ} \mathrm{C}$. Nitrogen was the carrier gas, at 18 psig. $\mathrm{CH}_{4}$ in the biogas was analyzed by gas chromatography fitted with a thermal conductivity detector (GOW-MAC 580 series). The chromatograph was also equipped with an alltech column model CTR-1, 6ft x 1/4". The operation temperatures were $28^{\circ} \mathrm{C}, 200{ }^{\circ} \mathrm{C}$, and $130^{\circ} \mathrm{C}$ for the column, detector and injector, respectively.

\section{Calculations and statistical analysis}

We defined a convenient mass load ratio (z) that indicates the mass load proportion of ZVI to the applied mass of PCE, in units of g ZVI/ g PCE (Eq. 1; Bretón-Deval et al. 2016).

$\mathrm{z}=\mathrm{m}_{\mathrm{ZVI}}(\mathrm{g}) / \mathrm{m}_{\mathrm{PCE}}(\mathrm{g})$

where $m_{\mathrm{ZVI}}$ is the mass of ZVI in the bed of the side filter (sand-ZVI), $m_{P C E}$ is the mass of PCE fed to the bioreactor in a given period of operation. For continuous bioreactors as in our case,

$\mathrm{m}_{\mathrm{PCE}}=\mathrm{Q} *[\mathrm{PCE}]_{\text {influent }}$

where $\mathrm{Q}$ is the flow-rate of influent, and $[\mathrm{PCE}]_{\text {influent }}$ is the concentration of PCE in the feeding to the bioreactor, namely $80 \mathrm{mg} / \mathrm{L}$.

For batch bioreactors, $\mathrm{m}_{\mathrm{PCE}}$ is simply the mass of PCE loaded into the bioreactor, or

$\mathrm{m}_{\mathrm{PCE}}=\mathrm{V}^{*}[\mathrm{PCE}]_{\text {influent }}$

where $\mathrm{V}$ is the working volume of the batch bioreactor. 
Results of most response variables of the experiment were subjected to analysis of variance with software minitab 17, Minitab Inc. (Pennsylvania, State College, USA).

\section{RESULTS AND DISCUSSION}

The table I shows the results of period 1, performance of FBBRs in 168 days under conditions of simultaneous electron acceptors, and the first $15 \mathrm{~d}$ of period 2 where the FBBRs performance was impacted by feeding $80 \mathrm{mg}$ PCE/L. The tables II to $\mathbf{V}$ display the concentrations of metabolites of the reductive dehalogenation of PCE in effluents and solid matrices of the relevant bioreactors. The figure 2 shows the time course the PCE and metabolites in the effluents of four bioreactors.

\section{Effect of electron acceptor combination in bioreac- tor performance in period 1}

First, the effect of electron acceptor on reactors performance in the period 1 is presented and discussed. Herein after, the expression supplementary material document ANNEX 1 will be abbreviated as SMA1. In period 1, removal efficiency of COD $\left(\eta_{\mathrm{COD}}\right)$ (Table I.I Supplementary Material document ANNEX 1 -SMA1-), TKN (Table I.I SMA1), and SOUR of bio-particles (Table I.III SMA1), were essentially similar in the four FBBRs (all with $\mathrm{p}>$ 0.05). SOUR was in the range 1.01 to $1.12 \mathrm{mmol} \mathrm{O}_{2} / \mathrm{g}$ VSS $\cdot h$. These values were close to that reported by Madoni et al. (1999) who reported $1.9-1.1 \mathrm{mmol}$ $\mathrm{O}_{2} / g$ VSS $\cdot h$ in activated sludge from a wastewater treatment plant. Significant SOUR values would be the presence of aerobic heterotrophic or facultative anaerobic microorganisms. The SMA observed in the reactors in period 1 was in the range reported by Schmidt and Ahring (1996), i.e., 0.41-1.75 mmol $\mathrm{CH}_{4} / \mathrm{g}$ VSS$\cdot h$ for anaerobic granular sludges from upflow anaerobic sludge blanket reactors.

As it could be expected, the FBBRs with the same simultaneous electron acceptor combination exhibited similar performance in key parameters (e.g. MD: removal efficiency of nitrate $-\eta_{\mathrm{NO}^{-}}{ }^{-}, \mathrm{TKN}, \mathrm{SMA}$ and SDA; andPAM:-DO, TKN, SMA and SOUR; TableI). This suggested that results of FBBRs of a given kind were quite reproducible.

However, the parameters $\mathrm{pH}$, methane productivity $\left(\mathrm{I}_{\mathrm{CH} 4}\right), \mathrm{CH}_{4}$ in biogas, SMA and SDA were slightly different depending on the regime of simultaneous electron acceptors. For instance, methane-related variables such as methane productivity (Table I.IV SMA1,

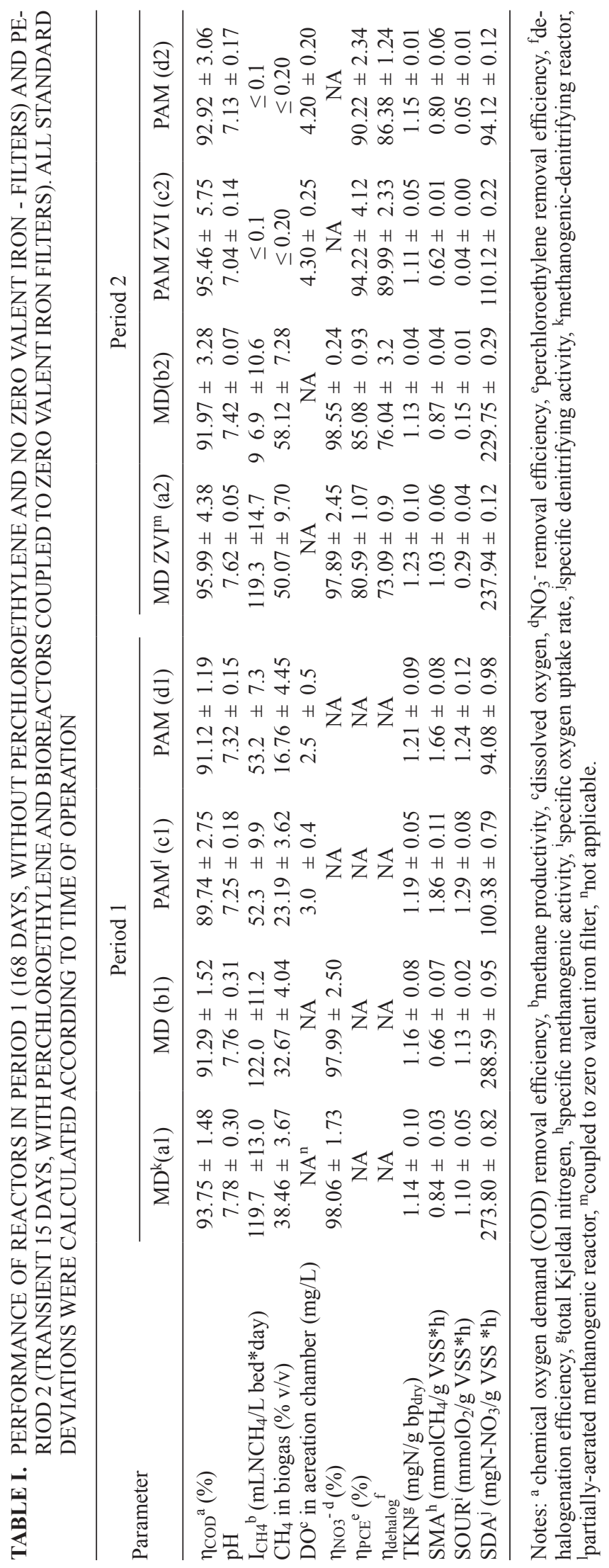


TABLE II. CONCENTRATIONS OF PERCHLOROETHYLENE AND METABOLITES DETECTED IN EFFLUENTS (IN mg/L)

\begin{tabular}{lccccc}
\hline \multicolumn{5}{c}{ Fluidized bed bioreactor } \\
\cline { 2 - 6 } & MD $^{\mathrm{a}}-\mathrm{ZVI}^{\mathrm{b}}$ & $\mathrm{MD}$ & PAM $^{\mathrm{c}}-\mathrm{ZVI}$ & PAM \\
\hline $\mathrm{PCE}^{\mathrm{d}}$ & $15.67 \pm 1.11$ & $11.96 \pm 1.93$ & $4.65 \pm 3.11$ & $7.81 \pm 3.12$ \\
$\mathrm{TCE}^{\mathrm{e}}$ & $11.85 \pm 0.90$ & $6.49 \pm 1.08$ & $1.17 \pm 0.12$ & $1.82 \pm 0.14$ \\
$\mathrm{t}^{-D C E}$ & $0.028 \pm 0.003$ & $0.05 \pm 0.003$ & $0.037 \pm 0.003$ & $0.007 \pm 0.003$ \\
VC $^{\mathrm{f}}$ & $\leq 0.002$ & $\leq 0.002$ & $\leq 0.002$ & $\leq 0.002$ \\
Ethylene & $\leq 0.001$ & $\leq 0.001$ & $0.007 \pm 0.001$ & $\leq 0.001$ \\
\hline
\end{tabular}

Notes: ${ }^{a}$ methanogenic-denitrifying reactor, ${ }^{b}$ zero valent iron filter coupled, ${ }^{c}$ methanogenic partiallyaerated reactor, ${ }^{\mathrm{d}}$ perchloroethylene, ${ }^{\mathrm{e}}$ trichloroethylene, ${ }^{\mathrm{f}}$ trans $1-2$ dichloroethylene, ${ }^{\mathrm{g}}$ vinyl chloride. cis-1-2 and 1-1 dichloroethylene $<0.002 \mathrm{mg} / \mathrm{L}$

TABLE III. CONCENTRATIONS OF PERCHLOROETHYLENE AND METABOLITES DETECTED IN BED BIO-PARTICLES $(\mathrm{mg} / \mathrm{g})$

\begin{tabular}{lcrrr}
\hline & \multicolumn{4}{c}{ Fluidized bed bioreactor } \\
\cline { 2 - 5 } & MD $^{\mathrm{a}}-\mathrm{ZVI}^{\mathrm{b}}$ & \multicolumn{1}{c}{$\mathrm{MD}$} & PAM $^{\mathrm{c}}-$ ZVI & \multicolumn{1}{c}{ PAM } \\
\hline PCE $^{\mathrm{d}}$ & $<0.002$ & $<0.002$ & $<0.002$ & $<0.002$ \\
$\mathrm{TCE}^{\mathrm{e}}$ & $<0.002$ & 0.030 & $<0.002$ & $<0.002$ \\
t-DCE $^{\mathrm{f}}$ & $<0.003$ & $<0.003$ & $<0.003$ & $<0.003$ \\
VC $^{\mathrm{g}}$ & $<0.002$ & 0.045 & 0.059 & 0.034 \\
Ethylene & $<0.001$ & $<0.001$ & $<0.001$ & $<0.001$ \\
\hline
\end{tabular}

Notes: ${ }^{a}$ methanogenic-denitrifying reactor, ${ }^{b}$ zero valent iron filter coupled, ${ }^{\mathrm{c}}$ methanogenic partially-aerated reactor, ${ }^{\mathrm{d}}$ perchloroethylene, etrichloroethylene, ${ }^{\mathrm{f}}$ trans 1-2 dichloroethylene,

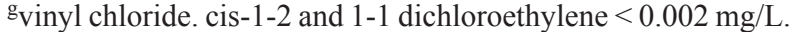

TABLE IV. AVERAGE PERCHLOROETHYLENE AND METABOLITES DETECTED IN ACTIVATED CARBON OF BIOGAS TRAP (mg/g)

\begin{tabular}{lcrcr}
\hline & \multicolumn{4}{c}{ Fluidized bed bioreactor } \\
\cline { 2 - 5 } & MD $^{\mathrm{a}}-\mathrm{ZVI}^{\mathrm{b}}$ & $\mathrm{MD}$ & PAM $^{\mathrm{c}}-\mathrm{ZVI}$ & \multicolumn{1}{c}{ PAM } \\
\hline PCE $^{\mathrm{d}}$ & $<0.002$ & $<0.002$ & $<0.002$ & $<0.002$ \\
$\mathrm{TCE}^{\mathrm{e}}$ & $<0.002$ & $<0.002$ & $<0.002$ & $<0.002$ \\
t-DCE $^{\mathrm{f}}$ & $<0.002$ & $<0.002$ & $<0.002$ & $<0.002$ \\
VC $^{\mathrm{g}}$ & 0.180 & 0.183 & 0.680 & 0.250 \\
Ethylene & $<0.002$ & $<0.002$ & $<0.002$ & $<0.002$ \\
\hline
\end{tabular}

Notes: ${ }^{a}$ methanogenic-denitrifying reactor, ${ }^{b}$ zero valent iron filter coupled, ${ }^{\mathrm{c}}$ methanogenic partially-aerated reactor, ${ }^{\mathrm{d}}$ perchloroethylene, etrichloroethylene, ${ }^{\mathrm{f}}$ trans 1-2 dichloroethylene, $\mathrm{g}_{\mathrm{Vinyl}}$ chloride. cis-1-2 and 1-1 dichloroethylene $<0.002 \mathrm{mg} / \mathrm{L}$.

and SMA Table I.V SMA1) were significantly higher in MD than in PAM bioreactors (all $\mathrm{p}<0.017$ ), probably reflecting the fact that oxygen is a more aggressive than nitrate to methanogenic archaea. The SDA was significantly higher in MD than PAM bioreactors (Table I.VII SMA1, $\mathrm{p}<0.05$ ), probably because of
TABLE V. CONCENTRATIONS OF PERCHLOROETHYLENE AND METABOLITES DETECTED IN MEDIA OF SIDE ZERO VALENT IRON FILTERS $(\mathrm{mg} / \mathrm{g})$

\begin{tabular}{lcc}
\hline & \multicolumn{2}{c}{ Fluidized bed bioreactor } \\
\cline { 2 - 3 } & MD $^{\mathrm{a}}-\mathrm{ZVI}^{\mathrm{b}}$ & $\mathrm{PAM}^{\mathrm{c}}-\mathrm{ZVI}$ \\
\hline $\mathrm{PCE}^{\mathrm{d}}$ & $<0.002$ & $<0.002$ \\
$\mathrm{TCE}^{\mathrm{e}}$ & $<0.002$ & $<0.002$ \\
$\mathrm{t}^{\mathrm{DCCE}}$ & $<0.002$ & $<0.002$ \\
$\mathrm{VC}^{\mathrm{g}}$ & 0.380 & 0.630 \\
Ethylene & $<0.002$ & $<0.002$ \\
\hline
\end{tabular}

Notes: ${ }^{a}$ methanogenic-denitrifying reactor, ${ }^{b}$ zero valent iron filter coupled, ${ }^{c}$ methanogenic partially-aerated reactor, ${ }^{\mathrm{d}}$ perchloroethylene, ${ }^{e}$ trichloroethylene, ${ }^{f}$ trans 1-2 dichloroethylene,

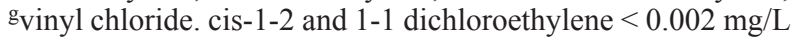

the selective pressure of continuously feeding nitrate salts to the MD units in order to provide denitrifying conditions.

\section{Effect of PCE in the feed-water to bioreactors on performance: period $1 \mathrm{vs}$. period 2}

The sudden addition of PCE $(80 \mathrm{mg} / \mathrm{L})$ impact on FBBRs performance will be discussed (period 2 vs. period 1). The abrupt change in feeding conditions resulted in changes of some of the key process parameters previously measured in the period 1 of the study. For the discussion below, we compare reactors b2 vs. b1 and d2 vs. d1, i.e., between periods. When comparing b2 vs. b1 and d2 vs. d1, the only difference is the PCE in the feed-water of period 2. Yet, when comparing a 2 vs. a1, or c 2 vs. 1 , the differences between reactors are double: the PCE in the feed-water of period 2 , and the coupling of side ZVI-sand filters to the bioreactors in period 2.

PCE did not seem to have a significant effect on the $\eta_{\text {COD }}$ (Table I.VIII SMA1, $\mathrm{p}=0.757$ ), $\mathrm{pH}$, $\eta_{\mathrm{NO}^{-}}{ }^{-}$, TKN (Table I.IX SMA1, $\mathrm{p}<0.10$ ) of the 

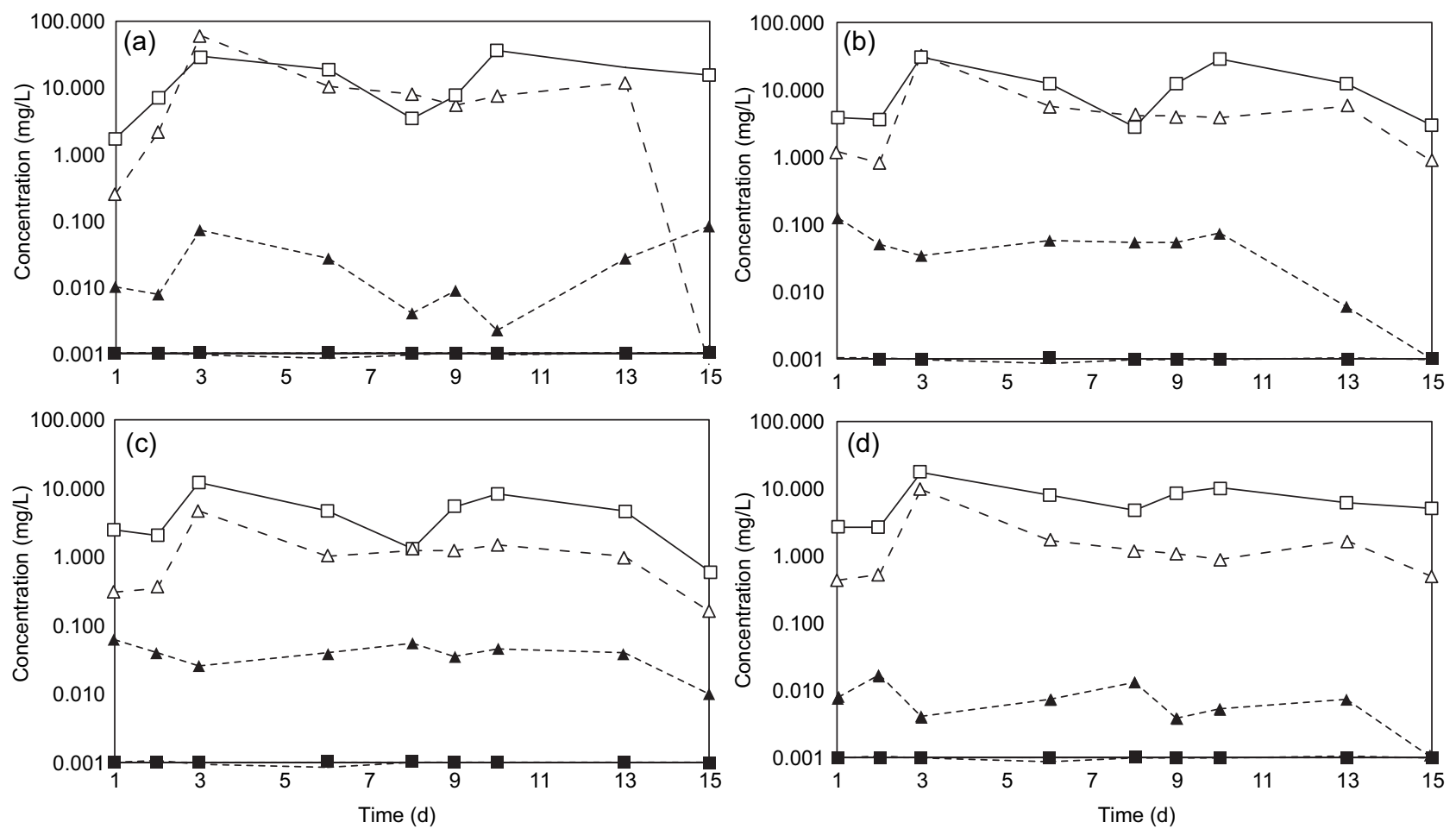

Fig. 2. Time course of perchlotoethylene and metabolite concentrations in period 2: (A) methanogenic-denitrifying reactor coupled to zero valent iron, (B) methanogenic-denitrifying reactor, (C) partially-aerated methanogenic reactor coupled to zero valent iron, (D) partially-aerated methanogenic reactor. Notes: perchlotoethylene: $\square-$, trichloroethylene: $-\square$, trans-dichloroethylene: $\_$, vinyl chloride: $-\square$, ethylene: $\checkmark$. cis-1-2 and 1-1 dichloroethylene: $<0.002 \mathrm{mg} / \mathrm{L}$

corresponding bioreactors, the values remained very similar between periods (Table I). In contrast, Min et al. (2008) found that nitrate reduction was inhibited by the presence of TCE $(1.4 \mathrm{mM}$ or 182 $\mathrm{mg} / \mathrm{L}$ ). Different trends could be due to immobilized biomass in our FBBRs whereas Min et al. worked with reed-sedge peat slurry incubated with sodium acetate as substrate in batch serum bottles. It is known that immobilized biomass can be more resistant to inhibitors and toxicants than disperse or flocculent biomass, due to physical and biochemical protection, knows as "shield" protection (Estrada-Vázquez et al. 2001, Estrada-Vázquez et al. 2003).

On the contrary, SOUR (Table I.X SMA1) and $\mathrm{I}_{\mathrm{CH} 4}$ (Table I.XI SMA1) were reduced significantly (both with $\mathrm{p}<0.000$ ) in all bioreactors upon PCE addition. Such evidence is in agreement with the results of the study of Kocamemi and Çeçen (2005) who found $88 \%$ SOUR reduction $(6.5$ to $0.75 \mathrm{mmol}$ $\mathrm{O}_{2} / \mathrm{g}$ VSS $\cdot h$ ) when a consortium enriched with nitrifying microorganisms was exposed to $50 \mathrm{mg}$ TCE/L.

The SMA significantly decreased in the PAM bioreactors in the period 2 (Table I.XII SMA1, $p$ $<0.004)$. In our work a PCE concentration of 80 $\mathrm{mg} / \mathrm{L}$ was associated to a $30-60 \%$ fall of SMA in
PAM bioreactors. Sponza (2003) reported a $75 \%$ SMA reduction (i.e., from 1.83 to $0.43 \mathrm{mmol} \mathrm{CH}_{4} /$ $\mathrm{g}$ TSS$\cdot h)$ after $60-\mathrm{d}$ incubation of flocculent sludge with initial $40 \mathrm{mg}$ PCE/L in a completely stirred tank of a yeast baker factory treatment plant.

The effect of SEA on the specific denitriying activity SDA was very significant (Table I.XIII SMA1, $p$ $<0.001$ ) with SDA of MD $>>$ SDA of PAM (Table I) which could be expected due to the selective pressure of the presence of nitrate in the feeding to MD bioreactors. The factor PCE in the feed-water only negatively affected the SDA of the MD reactors (by ca. $20 \%$, Table I), but it did not affect the SDA of the PAM units.

The $\mathrm{I}_{\mathrm{CH} 4}$ decrease observed in this study due to PCE was very significant (Table I.XI SMA1, $p<$ 0.001 ) and was more negatively affected in PAM than in MD (Table I). The overall order of decrease was similar to that reported by Bereded-Samuel et al. (1996). They found an $\mathrm{IC}_{50}=10 \mathrm{mg} / \mathrm{L} \mathrm{PCE}$ (0-100 mg PCE/L) in the methanogenesis for a methanogenic consortium fed with methanol and PCE. In addition, Ohandja and Stuckey (2010) observed that $40 \mathrm{mg}$ PCE/L caused a $50 \%$ drop of methane production in a methanogenic community 
previously acclimated to $15 \mathrm{mg}$ PCE/L in a PAM reactor membrane bioreactor.

In summary, there was a negative effect of PCE on the methanization variables of PAM bioreactors $\left(\mathrm{I}_{\mathrm{CH} 4}\right.$, SMA, with $\left.\mathrm{p}<0.001\right)$, only on the $\mathrm{I}_{\mathrm{CH} 4}$ of the MD bioreactors, and on the SOUR of all bioreactors in period 2 . The methane productivity $\mathrm{I}_{\mathrm{CH} 4}$ was drastically reduced by 99 and $21 \%$ in PAM y MD bioreactors, respectively. The methane concentration in biogas and the SMA showed parallel trends, both significantly decreased in PAM. The SOUR was drastically reduced (by $90 \%$ or higher) in both MD and PAM bioreactors. MD bioreactors exhibited higher SDA than the PAM ones $(\mathrm{p}<0.001$ Table I.XIII SMA1). This could be due to the selective pressure exerted by $\mathrm{NO}_{3}{ }^{-}$feeding on $\mathrm{MD}$ bioreactor microbial community during period 1 of the study.

\section{Effect of the regime of simultaneous electron ac- ceptors on bioreactor performance in period 2}

In the discussion below, the bioreactor contrasts are $\mathrm{c} 2$ and $\mathrm{d} 2$ vs. $\mathrm{a} 2$ and $\mathrm{b} 2$, that is, the influence of the regime of simultaneous electron on bioreactor performance already fed with a water containing 80 $\mathrm{mg} \mathrm{PCE} / \mathrm{L}$.

There was an important effect of electron acceptor configuration on both the PCE and dehalogenating removal efficiencies. The PCE removal efficiencies were in general higher in PAM than in MD. PAM ZVI exhibited the highest efficiency (94.22\%) followed by the PAM unit (Table I, Table I.XV SMA1, $\mathrm{p}<0.01)$. The factor coupling with the ZVI filter, did not have a statistically significant effect. The dehalogenating efficiencies showed a parallel trend to the PCE removal ones (Table VI, $\mathrm{p}<0.001$; Table I.XVI SMA1, Table II. II. SMA2).

TABLE VI. ANALYSIS OF VARIANCE OF THE DEHALOGENATION EFFICIENCY OF BIOREACTORS IN PERIOD 2

\begin{tabular}{lrrrrc}
\hline Source & DF $^{\mathrm{a}}$ & \multicolumn{1}{c}{$\mathrm{SS}^{\mathrm{b}}$} & \multicolumn{1}{c}{ MSS $^{\mathrm{c}}$} & F-value & P-value \\
\hline Model & 3 & 392.743 & 130.914 & 29.66 & 0.003 \\
Linear & 2 & 371.227 & 185.613 & 42.05 & 0.002 \\
SEA $^{\mathrm{d}}$ & 1 & 371.009 & 371.009 & 84.05 & 0.001 \\
ZVI $^{\mathrm{e}}$ & 1 & 0.218 & 0.218 & 0.05 & 0.835 \\
2-Way & & & & & \\
Interactions & 1 & 21.517 & 21.517 & 4.87 & 0.092 \\
SEA*ZVI & 1 & 21.517 & 21.517 & 4.87 & 0.092 \\
Error & 4 & 17.656 & 4.414 & & \\
Total & 7 & 410.4 & & & \\
\hline
\end{tabular}

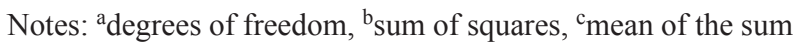
of squares, ${ }^{\mathrm{d}}$ simultaneous electron acceptors, ${ }^{\mathrm{e}}$ zero valent iron
In contrast, there was no significant effect of electron acceptor combination on the removal efficiency of organic matter (as COD): their grouped values were similar irrespective of the electron acceptor, i.e., $94 \%$ average for both PAM and MD bioreactors, (Table I and Table I.XVII SMA1, p $>0.9$ ). Interestingly, the $\eta_{\mathrm{COD}}$ was slightly superior for bioreactors equipped with side ZVI-sand filters but this was not statistically significant $(\mathrm{p}>0.33$, Table I.XVII SMA1).

The concentrations of PCE and TCE in effluents mirrored the trends of the removal efficiency of PCE, as expected (Table II.I SMA2). In general, concentrations were higher in MD than in PAM. The side ZVI-sand filter only had a significant positive effect on decreasing PCE and TCE concentrations (Table I. XVIII SMA1, $p<0.001$ ) for the PAM-ZVI but not for the MD-ZVI.

It is remarkable that there was presence of ethylene in the effluent of PAM-ZVI, this was encouraging and consistent with its high removal efficiencies of PCE and dehalogenation. It strongly suggests that PCE degradation was more effective in this bioreactor, likely due to the combined effects of the electron acceptor configuration and the abiotic contribution to degradation of the ZVI in the filter (Harendra and Vipulanandan 2008).

Regarding the concentration of metabolites on the bed bio-particles of the reactors, there was a noticeable accumulation of $\mathrm{VC}$ compared to the concentrations of the other metabolites (Table II, Table III.II SMA3). There was an effect of the electron acceptor configuration on metabolite pattern: the bio-particles in PAM units exhibited the highest concentrations of VC. The latter was consistent with the higher PCE removal efficiencies and dehalogenations efficiencies in the same reactors because it was a lateral evidence that the dechlorination of PCE proceeded further to the steps TCE and DCE. However, the VC concentrations were in general, low-to-moderate, in the order of the hundredths of $\mathrm{mg} \mathrm{VC/g} \mathrm{bp}$. The pattern of accumulation of PCE metabolites in the activated carbon of the biogas trap (Table IV) paralleled the trends mentioned above for the accumulation in the bed bio-particles (Table III. II SMA3).

The methanization variables $\mathrm{I}_{\mathrm{CH} 4}$ (Table I. XIX SMA1, $p<0.001$ ), concentration of $\mathrm{CH}_{4}$ in biogas (Table I. XX SMA1, $\mathrm{p}<0.000$ ), and SMA (Table I.XXI SMA1, $p<0.002$ ) in the PAM units were significantly lower than those in the MD bioreactors (Table I). On one hand, PAM reactors showed significantly higher removals of PCE (i.e., lower PCE as well as TCE concentrations in the effluent) than 
the MD ones. On the other hand, methanogenesis was distinctly affected by ZVI, PAM-FBBRs were more adversely impacted than the MD ones, given by significantly lower $\mathrm{I}_{\mathrm{CH} 4}$ and methane content in biogas $(\mathrm{p}<0.001$; Table I). This could be due to the combined adverse effects of both $\mathrm{O}_{2}$ and PCE on methanogenesis (Bereded-Samuel et al. 1996, Celis-García et al. 2004).

In summary, there was a significant effect of electron acceptor configuration on bioreactor variables related to PCE degradation and dechlorination (removal efficiency of perchloroethylene $-\eta_{\mathrm{PCE}^{-}}$, dehalogenation efficiency $-\eta_{\text {dehalog }}$, , metabolite profiles in effluents and solid matrices). In general PAM gave better results than MD and methanization seemed to be more negatively affected in PAM bioreactors.

\section{Effect of the coupling of the side ZVI-sand filter on bioreactor performance in period 2}

The effect of coupling side ZVI-sand filters to bioreactors was clear and generally positive in the PAM configuration, but no for the MD units. Indeed, the PAM-ZVI consistently showed higher $\eta_{\text {PCE }}, \eta_{\text {dehalog }}$ and slightly higher $\eta_{\mathrm{COD}}$ than the plain PAM reactor (Table I). Ethylene was present in the effluent of the PAM-ZVI unit, this suggested a more complete dechlorination of PCE and intermediate compounds in this reactor. The relatively slight positive effect of ZVI on PCE and its chlorinated derivatives removal compared to results of other authors (Alessi and $\mathrm{Li}$ 2001, Rosenthal et al. 2004, Harendra and Vipulanandan 2008), could be ascribed to low mass load ratios $\mathrm{z}(\mathrm{g} \mathrm{ZVI} / \mathrm{g}$ applied PCE) or to the relatively larger size of ZVI filings in this work. Herrera-López et al. (2008) did not observe a significantly $\eta_{\mathrm{PCE}}$ increment in bioreactors in a batch experiments, that had bio-particles and ZVI-sand bags. In effect, they found PCE removals of 99.85 and 99.75 in PAM and MD bioreactors with ZVI, respectively, compared to 99.58 and 99.69 removals in plain PAM and MD bioreactors, respectively. They used a z similar to that of our work in PAM, MD and bio-particles colonized with PCE-acclimated consortia. Herrera-López et al. (2008) stated that the positive effect of ZVI was not conclusive since the biological background removal of PCE (plain bioreactors, possibly due to a long previous process of acclimation to PCE) was already very high.

The effect of the ZVI filter on some methanization variables could not be assessed because their values were in the order of the detection levels for both the PAM-ZVI and the PAM reactors $\left(\mathrm{I}_{\mathrm{CH} 4}, \mathrm{CH}_{4}\right.$ in the biogas, Table I). Only the SMA in the PAM equipped with the side filter was lower (by $23 \%$ ) than that in the plain PAM unit (Table I). The biomass concentration and other specific activities were comparable, and no effect of the side filter could be discerned.

\section{CONCLUSION}

In general, during period 1 , few differences in performance were observed between MD and PAM reactors: SDA was higher for the MD reactors whereas SMA was higher in the PAM ones.

In period 2, PCE removals and dehalogenation efficiency in the range of 81 to $94 \%$ and 73 to 90 $\%$, respectively, were observed. The highest values corresponded to PAM bioreactors, particularly for the unit equipped with a ZVI filter. Slight positive effects of ZVI filter on PCE removal and the dehalogenation efficiencies were observed in the PAM ZVI bioreactor configuration.

It is concluded that the simultaneous electron acceptor type (PAM versus MD) had a significant effect on bioreactor performance as related to PCE removal variables, whereas the coupling to ZVI filters only had a slight positive effect on bioreactor performance for the PAM electron configuration.

\section{ACKOWLEDGMENTS}

The insightful suggestions and criticisms of Editors and anonymous Reviewers of RICA are gratefully acknowledged. They helped to significantly improve the revised manuscript. The authors gratefully acknowledge Consejo Nacional para la Ciencia y la Tecnología (CONCAyT, for its acronym in Spanish) for graduate scholarships to Cuauhtémoc Ulises Moreno-Medina and Luz María Bretón-Deval. CONACyT also granted infrastructure to the project 188221 for Héctor Mario Poggi-Varaldo. The excellent technical help of Mr. Rafael Hernández-Vera (Grupo de Biotecnología Ambiental y Energías Renovables, Centro de Investigación y de Estudios Avanzados from Instituto Politécnico Nacional) is appreciated. Centro de Investigación y de Estudios Avanzados from Instituto Politécnico Nacional (CINVESTAV, IPN), partially funded this research.

\section{REFERENCES}

Alessi D. S. and Li Z. H. (2001). Synergistic effect of cationic surfactants on perchloroethylene degradation 
by zero-valent iron. Environ. Sci. Technol. 35, 37133717. DOI: $10.1021 / \mathrm{es} 010564 \mathrm{i}$

Alther G. (2004). Has "in situ" remediation replaced "activated carbon pump and treat" in the groundwater market?. Proceeding. 18th International Activated Carbon Conference, Pittsburgh, PA, USA, October 19-20, 2006.

APHA (1998). Standard methods for the examination of water and wastewater, 20th ed. American Public Health Association. Washington, USA, 1325 pp.

Aschengrau A., Rogers S. and Ozonoff D. (2003). Perchloroethylene-contaminated drinking water and the risk of breast cancer: Additional results from Cape Cod, Massachusetts, USA. Environ. Health Persp. 111, 167-173.

Bagley D. M. and Gossett J. M. (1990). Tetrachloroethene transformation to trichloroethene and cis-1,2-dichloroethene by sulfate-reducing enrichment cultures. Appl. Environ. Microbiol. 56, 2511-2516.

Bereded-Samuel Y., Petersen J. and Skeen R. (1996). Effect of perchloroethylene (PCE) on methane and acetate production by a methanogenic consortium. Appl. Biochem. Biotech. 57-58, 915-922.

DOI: $10.1007 / \mathrm{BF} 02941772$

Bretón-Deval L., Rossetti S., Ríos-Leal E., Matturro B. and Poggi-Varaldo H. (2016). Effect of coupling zerovalent iron side filters on the performance of bioreactors fed with a high concentration of perchloroethylene. J. Environ. Eng. (ASCE) 142: 04016051, 1- 9. DOI: 10.1061/(ASCE)EE.1943-7870.0001093

Bruton T. A., Pycke B. F. G. and Halden R. U. (2015). Effect of nanoscale zero-valent iron treatment on biological reductive dechlorination: A review of current understanding and research needs. Crit. Rev. Env. Sci. Technol. 45, 1148-1175. DOI: 10.1080/10643389.2014.924185

Celis-García M. L. B., Ramírez F., Revah S., Razo-Flores E. and Monroy O. (2004). Sulphide and oxygen inhibition over the anaerobic digestion of organic matter: Influence of microbial immobilization type. Environ. Technol. 25, 1265-1275.

DOI: $10.1080 / 09593332508618367$

Chen L., Jin S., Fallgren P. H., Liu F. and Colberg P. J. (2013). Passivation of zero-valent iron by denitrifying bacteria and the impact on trichloroethene reduction in groundwater. Water Sci. Technol. 67, 1254-1259. DOI: $10.2166 /$ wst.2013.689

El-Fantroussi S., Naveau H. and Agathos S. N. (1998). Anaerobic dechlorinating bacteria. Biotechnol. Progr. 14, 167-188. DOI: $10.1021 / \mathrm{bp} 980011 \mathrm{k}$

EPA (1996). Pump-and-treat ground-water remediation: A guide for decision makers and practitioners. Guide. Office of Research and Development, Environmental Protection Agency. Washington, D.C., EUA, 90 pp.
Estrada-Vázquez C., Macarie H., Kato M. T., RodríguezVázquez R., Esparza-García F. and Poggi-Varaldo H. M. (2003). The effect of the supplementation with a primary carbon source on the resistance to oxygen exposure of methanogenic sludge. Water Sci. Technol. 48, 119-124.

Estrada-Vázquez C., Macarie H., Kato M. T., RodríguezVázquez R. and Poggi-Varaldo H. M. (2001). Resistencia a la exposición al oxígeno de lodos anaerobios suspendidos. Interciencia 26, 547-553.

Frascari D., Fraraccio S., Nocentini M. and Pinelli D. (2013). Aerobic/anaerobic/aerobic sequenced biodegradation of a mixture of chlorinated ethenes, ethanes and methanes in batch bioreactors. Bioresource Technol.128, 479-486.

DOI: $10.1016 /$ j.biortech.2012.10.026

Garibay-Orijel C., Ahring B. K., Rinderknecht-Seijas N. and Poggi-Varaldo H. M. (2006). A simple model for simultaneous methanogenic-denitrification systems. J. Chem. Technol. Biot. 81, 173-181.

DOI: $10.1002 /$ jetb. 1376

Garibay-Orijel C., Ríos-Leal E., García-Mena J. and Poggi-Varaldo H. M. (2005). 2,4,6-Trichlorophenol and phenol removal in methanogenic and partiallyaerated methanogenic conditions in a fluidized bed bioreactor. J. Chem. Technol. Biot. 80, 1180-1187. DOI: $10.1002 /$ jctb. 1313

Harendra S. and Vipulanandan C. (2008). Degradation of high concentrations of PCE solubilized in SDS and biosurfactant with $\mathrm{Fe} / \mathrm{Ni}$ bi-metallic particles. Colloid. Surface. A 322, 6-13.

DOI: $10.1016 /$ j.colsurfa.2008.02.009

Herrera-López D., García-Mena J. and Poggi-Varaldo H. M. (2008). Coupling continuous bioreactors with zero-valent iron filters: The effect on removal of high concentrations of perchloroethylene. Proceedings. In: Bruce M.S. (Ed.) Sixth International Conference Remediation of Chlorinated and Recalcitrant Compounds. Monterey, CA. May 19-22, 2008. Battelle Press, Columbus OH, USA, ISBN: 1-57477-163-9.

Kao C. M., Chen S. C., Wang J. Y., Chen Y. L. and Lee S. Z. (2003). Remediation of PCE-contaminated aquifer by an in situ two-layer biobarrier: laboratory batch and column studies. Water Res. 37, 27-38. DOI: 10.1016/S0043-1354(02)00254-3

Kocamemi B. A. and Çeçen F. (2005). Cometabolic degradation of TCE in enriched nitrifying batch systems. J. Hazard. Mater. 125, 260-265. DOI: 10.1016/j.jhazmat.2005.06.002

Kristensen G. H. and Jorgensen E. P. (1992). Characterization of functional microorganism groups and substrate in activated sludge and wastewater by AUR, NUR and OUR. Water Sci. Technol. 25, 43-57. 
Lagakos S. W., Wessen B. J. and Zelen M. (1986). An analysis of contaminated well water and health-effects in Woburn, Massachusetts. J. Am. Stat. Assoc. 81, 583596. DOI: 10.1080/01621459.1986.10478307

Madoni P., Davoli D. and Guglielmi L. (1999). Response of sOUR and AUR to heavy metal contamination in activated sludge. Water Res. 33, 2459-2464.

DOI: 10.1016/S0043-1354(98)00455-2

Majone M., Verdini R., Aulenta F., Rossetti S., Tandoi V., Kalogerakis N., Agathos S., Puig S., Zanaroli G. and Fava F. (2015). In situ groundwater and sediment bioremediation: barriers and perspectives at European contaminated sites. New Biotechnol. 32, 133-146. DOI: 10.1016/j.nbt.2014.02.011

Min J. E., Kim M., Pardue J. H. and Park J. W. (2008). Reduction of trichloroethylene and nitrate by zero-valent iron with peat. J. Environ. Sci. Health A 43, 144-153. DOI: $10.1080 / 10934520701781244$

Mitra S. and Gupta S. K. (2013). Biodegradation of tetrachloroethylene-rich synthetic wastewater in anaerobic hybrid reactor. Desalin. Water Treat. 51, 4506-4513. DOI: 10.1080/19443994.2013.770232

NTP (2016). Report on carcinogens, 14th Edition. Report. Department of Health and Human Services, Public Health Service, National Toxicology Program. Research Triangle Park, NC: EUA. http://ntp.niehs.nih. gov/go/roc14 05/12/2016

OEHHA (2001). Public health goal for tetrachloroethylene in drinking water. Technical Report. Office of Environmental Health Hazard Assessment. Sacramento, CA. EUA, 68 pp.

Ohandja D. G. and Stuckey D. C. (2010). Effect of perchloroethylene (PCE) and hydraulic shock loads on a membrane-aerated biofilm reactor (MABR) biodegrading PCE. J. Chem. Tech. Biot. 85, 294-301.

DOI: $10.1002 /$ jctb. 2307

Ohandja D. G. and Stuckey D. C. (2007). Biodegradation of PCE in a hybrid membrane aerated biofilm reactor. J. Environ. Eng. 133, 20-27. DOI: 10.1061/(ASCE)0733-9372(2007)133:1(20)

Paulu C., Aschengrau A. and Ozonoff D. (1999). Tetrachloroethylene-contaminated drinking water in Massachusetts and the risk of colon-rectum, lung, and other cancers. Environ. Health Persp. 107, 265-271.

Peng J. and Wan A.(1997). Measurement of Henry's constants of high-volatility organic compounds using a headspace autosampler. Environmental Science \& Technology 31, 2998-3003. DOI: 10.1021/es970240n

Poggi-Varaldo H. M., Moreno-Medina C. U., GalíndezMayer J., Ponce-Noyola M. T., Esparza-García F. J., Ríos-Leal E., Juárez-Ramírez C. and RinderknechtSeijas N. F. (2009). A review of zero-valent metals and biological treatment for the removal of chlorinated aliphatic compounds. New Biotechnol. 25, S255S256. DOI: 10.1016/j.nbt.2009.06.571

Reyna-Velarde R., Ríos-Leal E., Thalasso F., Foresti E., Rinderknecht-Seijas N. and Poggi-Varaldo H.M. (2005). Comparison of two fluidized bed reactors with simultaneous electron acceptors for the treatment of a perchloroethylene-contaminated effluent. In: In situ and onsite remediation-2005. (B.C. Alleman, M.E. Kelley, Eds.). Battelle Press, Columbus OH, USA. pp. J04-J08.

Rosenthal H., Adrian L. and Steiof M. (2004). Dechlorination of PCE in the presence of $\mathrm{Fe}-0$ enhanced by a mixed culture containing two Dehalococcoides strains. Chemosphere 55, 661-669.

DOI: $10.1016 / j$.chemosphere.2003.11.053

Rouquerol F., Rouquerol J. and Sing K. (1999). Adsorption by active carbons. In: Adsorption by powders and porous solids. (F. Rouquerol, J. Rouquerol, K. Sing, Eds). Academic Press, London, UK, pp. 237-285.

Sánchez M., Mosquera-Corral A., Méndez R. and Lema J. M. (2000). Simple methods for the determination of the denitrifying activity of sludges. Bioresource Technol. 75, 1-6. DOI: 10.1016/S0960-8524(00)00033-X

Schmidt J. E. and Ahring B. K. (1996). Granular sludge formation in upflow anaerobic sledge blanket (UASB) reactors. Biotechnol. Bioeng. 49, 229-246.

DOI: 10.1002/(SICI)1097-0290(19960205)49:3<229:: AID-BIT1>3.0.CO;2-M

Sorensen H. A. and Ahring B. K. (1993). Measurements of the specific methanogenic activity of anaerobic digestor biomas. Appl. Microbiol. Biot. 40, 427-431. DOI: $10.1007 / \mathrm{BF} 00170405$

Sponza D. T. (2003). Toxicity and treatability of carbontetrachloride and tetrachloroethylene in anaerobic batch cultures. Int. Biodeter. Biodegr. 51, 119-127.

DOI: $10.1016 / \mathrm{S} 0964-8305(02) 00095-1$

Wang S. M. and Tseng S. K. (2009). Reductive dechlorination of trichloroethylene by combining autotrophic hydrogen-bacteria and zero-valent iron particles. Bioresource Technol. 100, 111-117.

DOI: 10.1016/j.biortech.2008.05.033

Wentzel W. C., Ekama G. A. and Loewenthal R. E. (2003). Fundamentals of biological behaviour and wastewater strength tests. In: Handbook of water and wastewater microbiology. (M. Duncan, N.J. Horan, Eds.). Academic Press, London, UK, pp. 145-173. DOI: 10.1016/B978-012470100-7/50010-8

Zárate-Segura P., Ríos-Leal E., Esparza-García F., GarcíaMena J., Rinderknecht-Seijas N., Sanz J., Zaiat M. and Poggi-Varaldo H.M. (2005). Removal of perchloroethylene in two methanogenic-denitrifying continuous systems. In: In situ and onsite remediation-2005. (B.C. Alleman, M.E. Kelley, Eds.). Battelle Press, Columbus OH, USA. pp. 14-18. 
Zárate-Segura P. B., Ríos-Leal E., Esparza-García F., García-Mena J., Sanz J. L., Zaiat M. and Poggi-Varaldo H. M. (2004). Perchloroethylene removal in two anaerobic continuous systems. Interciencia 29, 562-567.

Zhou Y.-Z., Yang J., Wang X.-L., Pan Y.-Q., Li H., Zhou D., Liu Y.-D., Wang P., Gu J.-D., Lu Q., Qiu Y.-F. and Lin K.-F. (2014). Bio-beads with immobilized anaerobic bacteria, zero-valent iron, and active carbon for the removal of trichloroethane from groundwater. Environ Sci. Pollut. R. 21, 11500-11509.

DOI: $10.1007 / \mathrm{s} 11356-014-3110-6$
Zhu L., Lin H., Qi J. and Xu X. (2013). Enhanced transformation and dechlorination of p-chloronitrobenzene in the combined ZVI-anaerobic sludge system. Environ. Sci. Pollut. R. 20, 6119-6127. DOI: $10.1007 / \mathrm{s} 11356-013-1631-\mathrm{z}$

Zolla V., Sethi R. and Di Molfetta A. (2007). Performance Assessment and Monitoring of a Permeable Reactive Barrier for the Remediation of a Contaminated Site. Am. J. Environ. Sci. 3, 158-165.

DOI: 10.3844/ajessp.2007.158.165 


\section{SUPPLEMENTARY MATERIAL}

\section{TRANSIENT PERFORMANCE OF TWO-ELECTRON REGIME BIOREACTORS THAT CONTAINED UNACCLIMATED BIOCATALYSTS AFTER FEEDING PERCHLOROETHYLENE}

\begin{abstract}
Annex 1. Summary of the analysis of variance used to support discussion of results

In period 1 when perchloroethylene (PCE) was absent from the feedingwater and no zero valent iron (ZVI) filter was coupled, there was only one factor to compare: the regime of simultaneous electron acceptor.

Between period 1 and 2, the bioreactors in period 1 (two simultaneous electron acceptor- SEA-, no PCE and no ZVI filter) can be compared to selected bioreactors in period 2 (two SEA, PCE in the feedwater, no ZVI filter). That is, another factorial experiment with two factors at two levels (SEA, either partiallyaerated methanogenic - PAM- and methanogenicdenitrifying -MD-; PCE in the feedingwater, either 0 or $80 \mathrm{mg} / \mathrm{L}$ ).
\end{abstract}

In period 2 when PCE was supplemented to the feedingwater, the experimental design was a factorial $2^{2}$. Factors were the regime of simultaneous electron acceptor (SEA, either PAM or MD), and coupled to ZVI side filters. All bioreactors contained biocatalysts that were not acclimated to PCE at the time that PCE feeding was started.

In this section the analysis of variance of several response variables in period 1 are shown when the factor is type of SEA. These results belong to the first experimental design described above (Tables I.I to I.VII). These results support the discussion of the effect of type of SEA on bioreactor performance in period 1. It is worth highlighting that in period 1 there was no PCE nor ZVI filter involved.

TABLE I.I. ANALYSIS OF VARIANCE OF CHEMICAL OXYGEN DEMAND REMOVAL EFFICIENCY

\begin{tabular}{lccccc}
\hline Source & Degrees of freedom & Sum of squares & Mean of the sum of squares & F-value & P-value \\
\hline Factor & 1 & 4.368 & 4.368 & 2.19 & 0.277 \\
Error & 2 & 3.978 & 1.989 & & \\
Total & 3 & 8.346 & & & \\
\hline
\end{tabular}

TABLE I.II. ANALYSIS OF VARIANCE OF SPECIFIC OXYGEN UPTAKE

\begin{tabular}{lccccc}
\hline Source & Degrees of freedom & Sum of squares & Mean of the sum of squares & F-value & P-value \\
\hline Factor & 1 & 0.0225 & 0.0225 & 26.47 & 0.056 \\
Error & 2 & 0.0017 & 0.00085 & & \\
Total & 3 & 0.0242 & & & \\
\hline
\end{tabular}

TABLE I.III. ANALYSIS OF VARIANCE OF TOTAL NITROGEN KJELDAHL

\begin{tabular}{lccccc}
\hline Source & Degrees of freedom & Sum of squares & Mean of the sum of squares & F-value & P-value \\
\hline Factor & 1 & 0.0025 & 0.0025 & & 0.072 \\
Error & 2 & 0.0004 & 0.0002 & 12.5 & 0.072 \\
Total & 3 & 0.0029 & & & \\
\hline
\end{tabular}

TABLE I.IV. ANALYSIS OF VARIANCE OF METHANE PRODUCTIVITY

\begin{tabular}{lccccc}
\hline Source & Degrees of freedom & Sum of squares & Mean of the sum of squares & F-value & P-value \\
\hline Factor & 1 & 4637.61 & 4637.61 & 3041.06 & 0.000 \\
Error & 2 & 3.05 & 1.53 & & \\
Total & 3 & 4640.66 & & & \\
\hline
\end{tabular}


TABLE I.V. ANALYSIS OF VARIANCE OF SPECIFIC METHANOGENIC ACTIVITY

\begin{tabular}{lccccc}
\hline Source & Degrees of freedom & Sum of squares & Mean of the sum of squares & F-value & P-value \\
\hline Factor & 1 & 1.0201 & 1.0201 & 56.36 & 0.017 \\
Error & 2 & 0.0362 & 0.0181 & & \\
Total & 3 & 1.0563 & & & \\
\hline
\end{tabular}

TABLE I.VI. ANALYSIS OF VARIANCE OF METHANE IN BIOGAS (\%)

\begin{tabular}{|c|c|c|c|c|c|c|}
\hline Source & Degrees of freedom & Sum of squares & Mean of the sum of squares & F-value & P-value & Source \\
\hline Factor & 1 & & 243.05 & 243.05 & 12.99 & 0.069 \\
\hline Error & 2 & & 37.43 & 18.72 & & \\
\hline Total & 3 & & 280.48 & & & \\
\hline
\end{tabular}

TABLE I.VII. ANALYSIS OF VARIANCE OF SPECIFIC DENITRIFYING ACTIVITY

\begin{tabular}{lccccc}
\hline Source & Degrees of freedom & Sum of squares & Mean of the sum of squares & F-value & P-value \\
\hline Factor & 1 & 33843.1 & 33843.1 & 523.82 & 0.002 \\
Error & 2 & 129.2 & 64.6 & & \\
Total & 3 & 33972.3 & & & \\
\hline
\end{tabular}

Now, we show the analysis of variance used to discuss the effect of feeding PCE on selected response variables of bioreactors not coupled to ZVI filters (Tables I.VIII to I.XIV). Bioreactor performances between period 1 and period 2 are compared; the factors were type of SEA (PAM and MD) and PCE in the feeding $(0$ and $80 \mathrm{mg} / \mathrm{L})$. The factor ZVI filter is not involved, that is, performance of bioreactors coupled to ZVI in period 2 was not considered. These results belong to the second experimental design described above.

TABLE I.VIII. ANALYSIS OF VARIANCE OF CHEMICAL OXYGEN DEMAND REMOVAL EFFICIENCY

\begin{tabular}{lccccc}
\hline Source & Degrees of freedom & Sum of squares & Mean of the sum of squares & F-value & P-value \\
\hline Model & 3 & 7.1524 & 2.3841 & 0.4 & 0.760 \\
Linear & 2 & 2.5316 & 1.2658 & 0.21 & 0.816 \\
SEA & 1 & 0.6498 & 0.6498 & 0.11 & 0.757 \\
PCE & 1 & 1.8818 & 1.8818 & 0.32 & 0.603 \\
2-Way Interactions & 1 & 4.6208 & 4.6208 & 0.78 & 0.427 \\
SEA*PCE & 1 & 4.6208 & 4.6208 & 0.78 & 0.427 \\
Error & 4 & 23.6976 & 5.9244 & & \\
Total & 7 & 30.85 & & & \\
\hline
\end{tabular}

Notes: SEA = simultaenous electron acceptor regime, $\mathrm{PCE}=$ perchloroethylene in the feedingwater

TABLE I.IX. ANALYSIS OF VARIANCE OF TOTAL NITROGEN KJELDAHL

\begin{tabular}{lccccc}
\hline Source & Degrees of freedom & Sum of squares & Mean of the sum of squares & F-value & P-value \\
\hline Model & 3 & 0.0053 & 0.0017 & 3.45 & 0.131 \\
Linear & 2 & 0.0049 & 0.0024 & 4.74 & 0.088 \\
SEA & 1 & 0.0024 & 0.0024 & 4.74 & 0.095 \\
PCE & 1 & 0.0024 & 0.0024 & 4.74 & 0.095 \\
2-Way Interactions & 1 & 0.0004 & 0.0004 & 0.87 & 0.403 \\
SEA*PCE & 1 & 0.0004 & 0.0004 & 0.87 & 0.403 \\
Error & 4 & 0.0020 & 0.0005 & & \\
Total & 7 & & & & \\
\hline
\end{tabular}

Notes: $\mathrm{SEA}=$ simultaenous electron acceptor regime, $\mathrm{PCE}=$ perchloroethylene in the feedingwater 
TABLE I.X. ANALYSIS OF VARIANCE OF SPECIFIC OXYGEN UPTAKE

\begin{tabular}{lcccrc}
\hline Source & Degrees of freedom & Sum of squares & Mean of the sum of squares & F-value & P-value \\
\hline Model & 3 & 2.4087 & 0.8029 & 1693.88 & 0.000 \\
Linear & 2 & 2.37745 & 1.18872 & 2507.86 & 0.000 \\
SEA & 1 & 0.00125 & 0.00125 & 2.64 & 0.180 \\
PCE & 1 & 2.3762 & 2.3762 & 5013.08 & 0.000 \\
2-Way Interactions & 1 & 0.03125 & 0.03125 & 65.93 & 0.001 \\
SEA*PCE & 1 & 0.03125 & 0.03125 & 65.93 & 0.001 \\
Error & 4 & 0.0019 & 0.00047 & & \\
Total & 7 & 2.4106 & & & \\
\hline
\end{tabular}

Notes: $\mathrm{SEA}=$ simultaenous electron acceptor regime, $\mathrm{PCE}=$ perchloroethylene in the feedingwater

TABLE I.XI. ANALYSIS OF VARIANCE OF METHANE PRODUCTIVITY

\begin{tabular}{lccccc}
\hline Source & Degrees of freedom & Sum of squares & Mean of the sum of squares & F-value & P-value \\
\hline Model & 3 & 16941.6 & 5647.2 & 199.61 & 0.000 \\
Linear & 2 & 16529.8 & 8264.9 & 292.14 & 0.000 \\
SEA & 1 & 13596 & 13596 & 480.58 & 0.000 \\
PCE & 1 & 2933.8 & 2933.8 & 103.7 & 0.001 \\
2-Way Interactions & 1 & 411.8 & 411.8 & 14.56 & 0.019 \\
SEA*PCE & 1 & 411.8 & 411.8 & 14.56 & 0.019 \\
Error & 4 & 113.2 & 28.3 & & \\
Total & 7 & 17054.8 & & & \\
\hline
\end{tabular}

Notes: $\mathrm{SEA}=$ simultaenous electron acceptor regime, $\mathrm{PCE}=$ perchloroethylene in the feedingwater

TABLE I.XII. ANALYSIS OF VARIANCE OF SPECIFIC METHANOGENIC ACTIVITY

\begin{tabular}{lccccc}
\hline Source & Degrees of freedom & Sum of squares & Mean of the sum of squares & F-value & P-value \\
\hline Model & 3 & 1.3778 & 0.45927 & 44.49 & 0.002 \\
Linear & 2 & 0.7946 & 0.3973 & 38.48 & 0.002 \\
SEA & 1 & 0.4418 & 0.4418 & 42.79 & 0.003 \\
PCE & 1 & 0.3528 & 0.3528 & 34.17 & 0.004 \\
2-Way Interactions & 1 & 0.5832 & 0.5832 & 56.49 & 0.002 \\
SEA*PCE & 1 & 0.5832 & 0.5832 & 56.49 & 0.002 \\
Error & 4 & 0.0413 & 0.01032 & & \\
Total & 7 & 1.4191 & & & \\
\hline
\end{tabular}

Notes: SEA = simultaenous electron acceptor regime, $\mathrm{PCE}=$ perchloroethylene in the feedingwater

TABLE I.XIII. ANALYSIS OF VARIANCE OF SPECIFIC DENITRIFYING ACTIVITY

\begin{tabular}{lcccrc}
\hline Source & Degrees of freedom & Sum of squares & Mean of the sum of squares & F-value & P-value \\
\hline Model & 3 & 53726.7 & 17908.9 & 553.97 & 0.000 \\
Linear & 2 & 52558.6 & 26279.3 & 812.89 & 0.000 \\
SEA & 1 & 51070.5 & 51070.5 & 1579.74 & 0.000 \\
PCE & 1 & 1488.1 & 1488.1 & 46.03 & 0.002 \\
2-Way Interactions & 1 & 1168.1 & 1168.1 & 36.13 & 0.004 \\
SEA*PCE & 1 & 1168.1 & 1168.1 & 36.13 & 0.004 \\
Error & 4 & 129.3 & 32.3 & & \\
\hline
\end{tabular}

Notes: $\mathrm{SEA}=$ simultaenous electron acceptor regime, $\mathrm{PCE}=$ perchloroethylene in the feedingwater 
TABLE I.XIV. ANALYSIS OF VARIANCE OF METHANE IN BIOGAS (\%)

\begin{tabular}{lccccc}
\hline Source & Degrees of freedom & Sum of squares & Mean of the sum of squares & F-value & P-value \\
\hline Model & 3 & 3601.64 & 1200.55 & 53.73 & 0.001 \\
Linear & 2 & 2705.72 & 1352.86 & 60.55 & 0.001 \\
SEA & 1 & 2701.86 & 2701.86 & 120.93 & 0.000 \\
PCE & 1 & 3.86 & 3.86 & 0.17 & 0.699 \\
2-Way Interactions & 1 & 895.91 & 895.91 & 40.1 & 0.003 \\
SEA*PCE & 1 & 895.91 & 895.91 & 40.1 & 0.003 \\
Error & 4 & 89.37 & 22.34 & & \\
Total & 7 & 3691.01 & & & \\
\hline
\end{tabular}

Notes: SEA = simultaenous electron acceptor regime, $\mathrm{PCE}=$ perchloroethylene in the feedingwater

In the following section we present the analysis of variance tables used to discuss the results obtained in period 2 of bioreactor operation (Tables I.XV to
I.XXIII). The factors were regime of SEA and coupling to ZVI filter. These results belong to the third experimental design described above.

TABLE I.XV. ANALYSIS OF VARIANCE OF PERCHLOROETHYLENE REMOVAL EFFICIENCY IN PERIOD 2

\begin{tabular}{lccccc}
\hline Source & Degrees of freedom & Sum of squares & Mean of the sum of squares & F-value & P-value \\
\hline Model & 3 & 212.317 & 70.772 & 11.81 & 0.019 \\
Linear & 2 & 176.277 & 88.138 & 14.71 & 0.014 \\
SEA & 1 & 176.156 & 176.156 & 29.4 & 0.006 \\
ZVI & 1 & 0.12 & 0.12 & 0.02 & 0.894 \\
2-Way Interactions & 1 & 36.04 & 36.04 & 6.01 & 0.070 \\
SEA*ZVI & 1 & 36.04 & 36.04 & 6.01 & 0.070 \\
Error & 4 & 23.971 & 5.993 & & \\
Total & 7 & 236.287 & & & \\
\hline
\end{tabular}

Notes: SEA = simultaenous electron acceptor regime, ZVI = side ZVI filter coupled to bioreactor

TABLE I.XVI. ANALYSIS OF VARIANCE OF DEHALOGENATION EFFICIENCY

\begin{tabular}{lccccc}
\hline Source & Degrees of freedom & Sum of squares & Mean of the sum of squares & F-value & P-value \\
\hline Model & 3 & 392.743 & 130.914 & 29.66 & 0.003 \\
Linear & 2 & 371.227 & 185.613 & 42.05 & 0.002 \\
SEA & 1 & 371.009 & 371.009 & 84.05 & 0.001 \\
ZVI & 1 & 0.218 & 0.218 & 0.05 & 0.835 \\
2-Way Interactions & 1 & 21.517 & 21.517 & 4.87 & 0.092 \\
SEA*ZVI & 1 & 21.517 & 21.517 & 4.87 & 0.092 \\
Error & 4 & 17.656 & 4.414 & & \\
Total & 7 & 410.4 & & & \\
\hline
\end{tabular}

Notes: SEA = simultaenous electron acceptor regime, $\mathrm{PCE}=$ perchloroethylene in the feedingwater 
TABLE I.XVII. ANALYSIS OF VARIANCE OF CHEMICAL OXYGEN DEMAND REMOVAL EFFICIENCY IN PERIOD 2

\begin{tabular}{lccccc}
\hline Source & Degrees of freedom & Sum of squares & Mean of the sum of squares & F-value & P-value \\
\hline Model & 3 & 22.7002 & 7.5667 & 0.43 & 0.745 \\
Linear & 2 & 21.605 & 10.8025 & 0.61 & 0.588 \\
SEA & 1 & 0.0882 & 0.0882 & 0 & 0.947 \\
ZVI & 1 & 21.5168 & 21.5168 & 1.21 & 0.332 \\
2-Way Interactions & 1 & 1.0952 & 1.0952 & 0.06 & 0.816 \\
SEA*ZVI & 1 & 1.0952 & 1.0952 & 0.06 & 0.816 \\
Error & 4 & 70.9215 & 17.7304 & & \\
Total & 7 & 93.6217 & & & \\
\hline
\end{tabular}

Notes: $\mathrm{SEA}=$ simultaenous electron acceptor regime, $\mathrm{PCE}=$ perchloroethylene in the feedingwater

TABLE I.XVIII. ANALYSIS OF VARIANCE OF TRICHLOROETHYLENE CONCENTRATION (MG/L) IN PERIOD 2

\begin{tabular}{lccccc}
\hline Source & Degrees of freedom & Sum of squares & Mean of the sum of squares & F-value & P-value \\
\hline Model & 3 & 146.963 & 48.988 & 99.46 & 0.000 \\
Linear & 2 & 128.903 & 64.452 & 130.85 & 0.000 \\
SEA & 1 & 117.811 & 117.811 & 239.19 & 0.000 \\
ZVI & 1 & 11.092 & 11.092 & 22.52 & 0.009 \\
2-Way Interactions & 1 & 18.060 & 18.060 & 36.67 & 0.004 \\
SEA*ZVI & 1 & 18.060 & 18.060 & 36.67 & 0.004 \\
Error & 4 & 1.970 & 0.493 & & \\
Total & 7 & 148.934 & & & \\
\hline
\end{tabular}

Notes: $\mathrm{SEA}=$ simultaenous electron acceptor regime, $\mathrm{PCE}=$ perchloroethylene in the feedingwater

TABLE I.XIX. ANALYSIS OF VARIANCE OF METHANE PRODUCTIVITY IN PERIOD 2

\begin{tabular}{lcccrc}
\hline Source & Degrees of freedom & Sum of squares & Mean of the sum of squares & F-value & P-value \\
\hline Model & 3 & 23825.4 & 7941.8 & 98.69 & 0.000 \\
Linear & 2 & 23574.8 & 11787.4 & 146.48 & 0.000 \\
SEA & 1 & 23323.7 & 23323.7 & 289.84 & 0.000 \\
ZVI & 1 & 251.1 & 251.1 & 3.12 & 0.152 \\
2-Way Interactions & 1 & 250.7 & 250.7 & 3.11 & 0.152 \\
SEA*ZVI & 1 & 250.7 & 250.7 & 3.11 & 0.152 \\
Error & 4 & 321.9 & 80.5 & & \\
Total & 7 & 24147.3 & & & \\
\hline
\end{tabular}

Notes: SEA = simultaenous electron acceptor regime, $\mathrm{PCE}=$ perchloroethylene in the feedingwater

TABLE I.XX. ANALYSIS OF VARIANCE OF METHANE IN BIOGAS (\%) IN PERIOD 2

\begin{tabular}{lccccc}
\hline Source & Degrees of freedom & Sum of squares & Mean of the sum of squares & F-value & P-value \\
\hline Model & 3 & 5874.68 & 1958.23 & 54.34 & 0.001 \\
Linear & 2 & 5842.32 & 2921.16 & 81.06 & 0.001 \\
SEA & 1 & 5809.88 & 5809.88 & 161.22 & 0.000 \\
ZVI & 1 & 32.44 & 32.44 & 0.9 & 0.396 \\
2-Way Interactions & 1 & 32.36 & 32.36 & 0.9 & 0.397 \\
SEA*ZVI & 1 & 32.36 & 32.36 & 0.9 & 0.397 \\
Error & 4 & 144.15 & 36.04 & & \\
Total & 7 & 6018.83 & & & \\
\hline
\end{tabular}

Notes: $\mathrm{SEA}=$ simultaenous electron acceptor regime, $\mathrm{PCE}=$ perchloroethylene in the feedingwater 
PERFORMANCE OF BIOREACTORS WITH TWO ELECTRON ACCEPTORS AFTER EXPOSURE OF PERCHLORETHYLENE 101

TABLE I.XXI. ANALYSIS OF VARIANCE OF SPECIFIC METHANOGENIC ACTIVITY IN PERIOD 2

\begin{tabular}{lccccc}
\hline Source & Degrees of freedom & Sum of squares & Mean of the sum of squares & F-value & P-value \\
\hline Model & 3 & 0.1732 & 0.057733 & 26.48 & 0.004 \\
Linear & 2 & 0.1154 & 0.0577 & 26.46 & 0.005 \\
SEA & 1 & 0.1152 & 0.1152 & 52.83 & 0.002 \\
ZVI & 1 & 0.0002 & 0.0002 & 0.09 & 0.777 \\
2-Way Interactions & 1 & 0.0578 & 0.0578 & 26.51 & 0.007 \\
SEA*ZVI & 1 & 0.0578 & 0.0578 & 26.51 & 0.007 \\
Error & 4 & 0.008722 & 0.002181 & & \\
Total & 7 & 0.181922 & & & \\
\hline
\end{tabular}

Notes: $\mathrm{SEA}=$ simultaenous electron acceptor regime, $\mathrm{PCE}=$ perchloroethylene in the feedingwater

TABLE I.XXII. ANALYSIS OF VARIANCE OF SPECIFIC DENITRIFYING ACTIVITY IN PERIOD 2

\begin{tabular}{lcccrc}
\hline Source & Degrees of freedom & Sum of squares & Mean of the sum of squares & F-value & P-value \\
\hline Model & 3 & 35026 & 11675.3 & 295439.92 & 0.000 \\
Linear & 2 & 34995.5 & 17497.8 & 442774.01 & 0.000 \\
SEA & 1 & 292.6 & 292.6 & 7403.57 & 0.000 \\
ZVI & 1 & 34703 & 34703 & 878144.45 & 0.000 \\
2-Way Interactions & 1 & 30.5 & 30.5 & 771.74 & 0.000 \\
SEA*ZVI & 1 & 30.5 & 30.5 & 771.74 & 0.000 \\
Error & 4 & 0.2 & 0 & 0.000 \\
Total & 7 & 35026.2 & & & \\
\hline
\end{tabular}

Notes: $\mathrm{SEA}=$ simultaenous electron acceptor regime, $\mathrm{PCE}=$ perchloroethylene in the feedingwater

TABLE I.XXIII. ANALYSIS OF VARIANCE OF SPECIFIC OXYGEN UPTAKE IN PERIOD 2

\begin{tabular}{lcccrc}
\hline Source & Degrees of freedom & Sum of squares & Mean of the sum of squares & F-value & P-value \\
\hline Model & 3 & 0.08095 & 0.026983 & 57.97 & 0.001 \\
Linear & 2 & 0.0697 & 0.03485 & 74.87 & 0.001 \\
SEA & 1 & 0.06125 & 0.06125 & 131.58 & 0.000 \\
ZVI & 1 & 0.00845 & 0.00845 & 18.15 & 0.013 \\
2-Way Interactions & 1 & 0.01125 & 0.01125 & 24.17 & 0.008 \\
SEA*ZVI & 1 & 0.01125 & 0.01125 & 24.17 & 0.008 \\
Error & 4 & 0.001862 & 0.000465 & & \\
Total & 7 & 0.082812 & & & \\
\hline
\end{tabular}

Notes: SEA = simultaenous electron acceptor regime, $\mathrm{PCE}=$ perchloroethylene in the feedingwater 
Annex 2. Organic chlorine balances and the dehalogenating efficiency

Tables II.I and II.II. of the annex 2 show data and results of organic chlorine balances and the dehalogenating efficiency as the key variable.

Particularly, Table II.II. corroborates, in more detail, the influence of factors in period 2 (SEA and ZVI side filters) on the main terms of the organic chlorine balance, and these, in turn, on the dehalogenation efficiency, the key parameter of bioreactor performance.

It can be seen that the main component of non removed organic chlorine was the concentration of PCE and metabolites in the effluents, whereas the contribution of non degraded organic chlorine attached to the various solid matrices were nearly one order of magnitude lower than that of the effluents.

Furthermore, organic chlorine in effluents of MD were higher than those in PAM units (by a factor 2.8 average), whereas the contributions of organic chlorine in solid matrices were of similar order. Coupling to ZVI did not seem to have a consistent effect on lowering the amount of non-removed organic chlorine in effluents or increasing the dehalogenating efficicency of bioreactors.

The consequences of these patterns are, in general:

- Non removed organic chlorine in liquid effluents were the major contributions to (and associated to lower values of) the dehalogenating efficicency

- A large part of the dehalogenating efficicency was due to biological degradation

- removal

- PAM effluents consistently had lower concentrations of organic chlorine than MD rectors, which impacted on higher dehalogenating efficicency of PAM reactors

- The effect of ZVI on organic chlorine balance was slightly favorable only for PAM units

TABLE II.I. CONCENTRATIONS OF PERCHLOROETHYLENEAND PERCHLOROETHYLENE METABOLITES FOUND IN THE BIOREACTORS, EFFLUENT IN mg/LAND FOR BIORREACTOR SOLIDS MATRIX IN mg/g

\begin{tabular}{|c|c|c|c|c|}
\hline & \multicolumn{4}{|c|}{ Fluidized bed bioreactor } \\
\hline & MD -ZVI & MD & PAM -ZVI & PAM \\
\hline $\mathrm{PCE}_{\mathrm{efl}}$ & $15.67 \pm 1.11$ & $11.96 \pm 1.93$ & $4.65 \pm 3.11$ & $7.81 \pm 3.12$ \\
\hline $\mathrm{TCE}_{\mathrm{efl}}$ & $11.85 \pm 0.90$ & $6.49 \pm 1.08$ & $1.17 \pm 0.12$ & $1.82 \pm 0.14$ \\
\hline $\mathrm{t}-\mathrm{DCE} \mathrm{E}_{\mathrm{efl}}$ & $0.028 \pm 0.003$ & $0.05 \pm 0.003$ & $0.037 \pm 0.003$ & $0.007 \pm 0.003$ \\
\hline $\mathrm{VC}_{\mathrm{efl}}$ & $\leq 0.002$ & $\leq 0.002$ & $\leq 0.002$ & $\leq 0.002$ \\
\hline $\mathrm{PCE}_{\mathrm{bp}}$ & $<0.002$ & $<0.002$ & $<0.002$ & $<0.002$ \\
\hline $\mathrm{TCE}_{\mathrm{bp}}$ & $<0.002$ & 0.030 & $<0.002$ & $<0.002$ \\
\hline $\mathrm{t}-\mathrm{DC} \mathrm{C}_{\mathrm{bp}} \mathrm{f}$ & $<0.003$ & $<0.003$ & $<0.003$ & $<0.003$ \\
\hline $\mathrm{VC}_{\mathrm{bp}}$ & $<0.002$ & 0.045 & 0.059 & 0.034 \\
\hline $\mathrm{PCE}_{\text {bgt }}$ & $<0.002$ & $<0.002$ & $<0.002$ & $<0.002$ \\
\hline $\mathrm{TCE}_{\mathrm{bgt}}$ & $<0.002$ & $<0.002$ & $<0.002$ & $<0.002$ \\
\hline $\mathrm{t}-\mathrm{DCE} \mathrm{E}_{\mathrm{bt}}$ & $<0.002$ & $<0.002$ & $<0.002$ & $<0.002$ \\
\hline $\mathrm{VC}_{\text {bgt }}$ & 0.180 & 0.183 & 0.680 & 0.250 \\
\hline $\mathrm{PCE}_{\mathrm{ZVI}}$ & $<0.002$ & N.Applic & $<0.002$ & N.Applic \\
\hline $\mathrm{TCE}_{Z \mathrm{VI}}$ & $<0.002$ & N.Applic & $<0.002$ & N.Applic \\
\hline $\mathrm{t}-\mathrm{DCE} \mathrm{ZVI}_{\mathrm{Z}}$ & $<0.002$ & N.Applic & $<0.002$ & N.Applic \\
\hline $\mathrm{VC}_{\mathrm{ZVI}}$ & 0.380 & N.Applic & 0.630 & N.Applic \\
\hline
\end{tabular}

Notes: $\mathrm{MD}=$ methanogenic-denitrifying, $\mathrm{PAM}=$ partially-aerated methanogenic, $\mathrm{ZVI}=$ zero-valent iron filter, $\mathrm{PCE}=$ perchloroethylene, $\mathrm{TCE}=$ trichloroethylene, $\mathrm{t}-\mathrm{DCE}=$ trans-dichloroethylene, $\mathrm{VC}$ $=$ vinyl chloride perchloroethylene, $\mathrm{efl}=$ effluent liquid, $\mathrm{bp}=$ bioparticle, $\mathrm{bgt}=$ biogas trap, N.Applic $=$ not applicable 
TABLE II.II. ORGANIC CHLORINE BALANCES AND DEHALOGENATION EFFICIENCIES

\begin{tabular}{lcccccr}
\hline Bioreactor & $\begin{array}{c}\text { Organic Cl in } \\
(\mathrm{mol})\end{array}$ & $\begin{array}{c}\text { Organic Cl org } \\
\text { out }^{\mathrm{b}} \text { in effluent } \\
(\mathrm{mol})\end{array}$ & $\begin{array}{c}\text { Organic Cl out } \\
\text { adsorbed onto solid } \\
\text { phases }^{\mathrm{c}}(\mathrm{mol})\end{array}$ & $\begin{array}{c}\text { Sum Cl out bio- } \\
\text { reactor } \\
(\mathrm{mol})\end{array}$ & $\begin{array}{c}\mathrm{Cl} \text { difference } \\
(\text { removed }) \\
(\mathrm{mol})\end{array}$ & $\begin{array}{c}\mathrm{h}_{\text {dehalog }}{ }^{\mathrm{d}} \\
(\%)\end{array}$ \\
\hline $\mathrm{MD}^{\mathrm{e}} \mathrm{ZVI}^{\mathrm{f}}$ & $2.89 \mathrm{E}-02$ & $7.41 \mathrm{E}-03$ & $3.77 \mathrm{E}-04$ & $7.79 \mathrm{E}-03$ & $2.12 \mathrm{E}-02$ & $73.09 \pm 0.91$ \\
$\mathrm{MD}^{\mathrm{PAM}} \mathrm{ZV}$ & $2.89 \mathrm{E}-02$ & $6.29 \mathrm{E}-03$ & $6.41 \mathrm{E}-04$ & $6.94 \mathrm{E}-03$ & $2.20 \mathrm{E}-02$ & $76.04 \pm 3.22$ \\
$\mathrm{PAM}^{\mathrm{g}}$ & $2.89 \mathrm{E}-02$ & $1.62 \mathrm{E}-03$ & $1.28 \mathrm{E}-03$ & $2.90 \mathrm{E}-03$ & $2.60 \mathrm{E}-02$ & $89.99 \pm 2.33$ \\
& $2.89 \mathrm{E}-02$ & $3.42 \mathrm{E}-03$ & $5.25 \mathrm{E}-04$ & $3.94 \mathrm{E}-03$ & $2.50 \mathrm{E}-02$ & $86.38 \pm 1.24$ \\
\hline
\end{tabular}

Notes: ${ }^{a}$ organic chlorine in the feeding, ${ }^{b}$ organic chlorine in bioreactors effluent, ${ }^{c}$ organic chlorine in the solid phases of bioreactors, ${ }^{\mathrm{d}}$ dehalogenation efficiency, ${ }^{\mathrm{e}}$ methanogenic-desnitrifiying, ${ }^{\mathrm{f}}$ zero valent iron, ${ }^{\mathrm{g}}$ partially-airated methanogenic

\section{Annex 3. Global mass balances of metabolites in period 2. \\ Results in Tables III.I and III.II are consistent with those of the balance of organic chlorine shown}

in Table II.II in Supplementary Material document Annex 2 (SMA2). In this regard, to a great extent the discussion of results in Table II.II SMA2 and those in Table III.I and III.II is similar, please go to SMA2.

TABLE III.I MASS OF PERCHLOROETHYLENE AND PERCHLOROETHYLENE METABOLITES IN EFFLUENTS OF BIOREACTORS DURING PERIOD 2 (TRANSIENT)

\begin{tabular}{lccccc}
\hline Bioreactor & $\begin{array}{c}\text { PCE }^{\mathrm{a}} \\
(\mathrm{mol})\end{array}$ & $\begin{array}{c}\text { PCE out eff } \\
(\mathrm{mol})\end{array}$ & $\begin{array}{c}\mathrm{TCE}^{\mathrm{b}} \text { out eff } \\
(\mathrm{mol})\end{array}$ & $\begin{array}{c}\mathrm{DCE}^{\mathrm{c}} \text { out eff } \\
(\mathrm{mol})\end{array}$ & $\begin{array}{c}\mathrm{VC}^{\mathrm{d}} \text { out eff } \\
(\mathrm{mol})\end{array}$ \\
\hline MD $^{\mathrm{e}} \mathrm{ZVI}^{\mathrm{f}}$ & $7.24 \mathrm{E}-03$ & $1.07 \mathrm{E}-03$ & $1.04 \mathrm{E}-03$ & $4.86 \mathrm{E}-06$ & $3.20 \mathrm{E}-08$ \\
$\mathrm{MD}^{\mathrm{g}}$ & $7.24 \mathrm{E}-03$ & $1.02 \mathrm{E}-03$ & $7.38 \mathrm{E}-04$ & $7.17 \mathrm{E}-06$ & $3.20 \mathrm{E}-08$ \\
PAM $^{\mathrm{g}}$ ZVI & $7.24 \mathrm{E}-03$ & $3.13 \mathrm{E}-04$ & $1.20 \mathrm{E}-04$ & $5.52 \mathrm{E}-06$ & $3.20 \mathrm{E}-08$ \\
PAM & $7.24 \mathrm{E}-03$ & $6.63 \mathrm{E}-04$ & $2.55 \mathrm{E}-04$ & $9.97 \mathrm{E}-07$ & $3.20 \mathrm{E}-08$ \\
\hline
\end{tabular}

Notes: ${ }^{a}$ perchloroethylene, ${ }^{b}$ trichloroethylene, ${ }^{\mathrm{c} D C E}=$ dichloroethylene, ${ }^{\mathrm{d}}$ vinyl chloride, ${ }^{\mathrm{e}}$ methanogenicdesnitrifiying, ${ }^{\mathrm{f}}$ zero valent iron, ${ }^{\mathrm{g}}$ partiallyairated methanogenic. eff $=$ effluent 


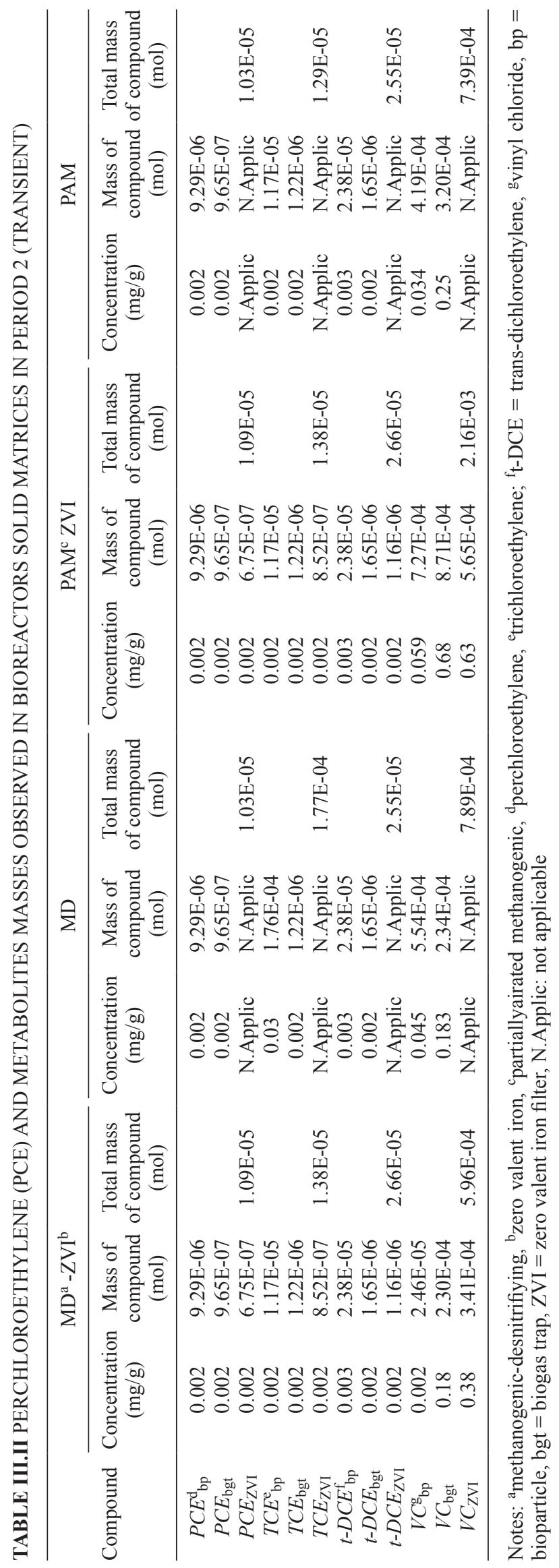

